University of Louisville

ThinkIR: The University of Louisville's Institutional Repository

Electronic Theses and Dissertations

7-1952

\title{
The relationship of social-emotional readiness to learning achievement as seen in a first grade class at Prestonia School.
}

Bernice Gabbert Cox

University of Louisville

Follow this and additional works at: https://ir.library.louisville.edu/etd

Part of the Educational Assessment, Evaluation, and Research Commons, and the Elementary Education Commons

\section{Recommended Citation}

Cox, Bernice Gabbert, "The relationship of social-emotional readiness to learning achievement as seen in a first grade class at Prestonia School." (1952). Electronic Theses and Dissertations. Paper 2880.

https://doi.org/10.18297/etd/2880

This Master's Thesis is brought to you for free and open access by ThinkIR: The University of Louisville's Institutional Repository. It has been accepted for inclusion in Electronic Theses and Dissertations by an authorized administrator of ThinkIR: The University of Louisville's Institutional Repository. This title appears here courtesy of the author, who has retained all other copyrights. For more information, please contact thinkir@louisville.edu. 
IAIIS OP STUDEIT: Bernice Gobbet Cox

TITLE OF PAPER: THE RELATIONSHIP OF SOCIAL-EMOTIONAL READINESS TO LEARNING ACHIEVEMENT AS SEEN IN A FIRST GRADE CLASS AT PRESTONIA SCHOOL.

APPROVED BY READING COMMITTEE COMPOSED OF THE FOLLOWING MEMBERS:

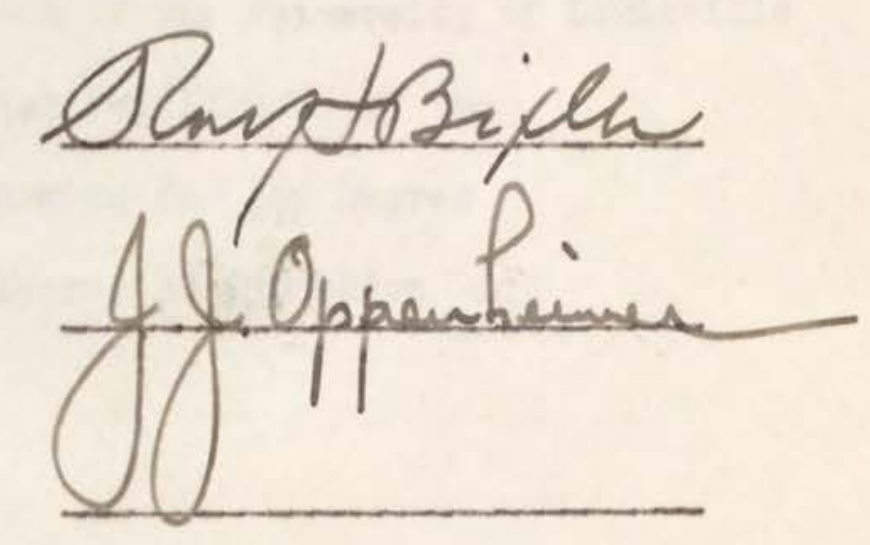

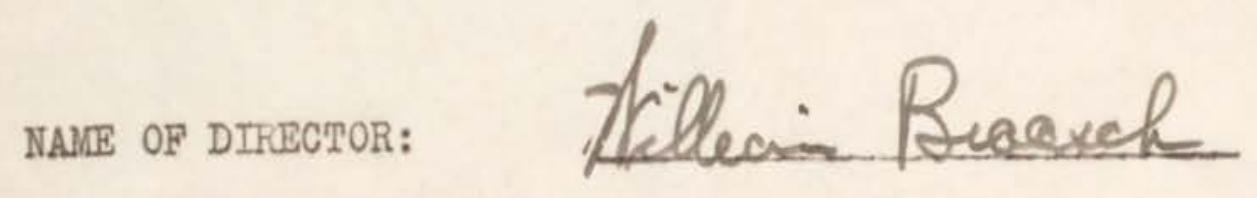
DATE: $0 \log 25,1952$ 


\title{
UNIVERSITY OF LOUISVILIE
}

THE RELATIONSHIP OF SOCIAL-EMOTIONAL READINESS TO

IEARNING ACHIEVEUENT AS SBEN IN A FIRST

GRADB CLASS AT PRESTONIA SCHOOL

\author{
A Professional Paper
}

Submitted to the Faculty

of the Graduate School of the University of Louisville

In Partial Fulfillment of the

Requirements for the Degree

of Master of Education

Department of Bducation

by

Bemice Gabbert Cox 


\section{TABLE OF CONTENTS}

Chapter

Page

I. THE PROBLEM AND ITS SCOPE

II. REVIEW OF THE ITMERATURE

III. METHODS

IV. INFORMATION ON THE THIRTY-FOUR FIRST GRADE SUBJECTS USED IN THIS STUDY

V. INFORMATION ON SOCIAI-EMOTIONAL STATUS OF THE THIRTY-FOUR SUBJECTS USED IN THIS STUDY

VI. RESUITS OF THE SOCIOIETRIC TESTS

VII. SUMMARY AND CONCLUSIONS

BIBIIOGRAPHY 
I. The Chronological Ages, Nental Ages, and Intelligence Quotients of Thirty-Four First Grade Pupils obtained from the Kuhlman-Anderson Intelligence Teist administered in October 1951.

II. Classification and Range of the Thirty-Four First Grade Pupils according to the Intelligence Test.

III. Results of Metropolitan Readiness Test administered to Thirty-Four Flrst Grade Pupils, October 19, 1951.

IV. The Classification on the Metropolitan Reading Readiness Test of Thirty-Four First Grade Pupils listed in Table III.

V. Frequency Distribution of Scores by Thirty-Four First Grade Pupils on Total Readiness.

VI. A Tabulation of the Childhood Diseases of ThirtyFour First Grade Subjects prior to entering and after entering School.

VII. Results of Dental Inspection of Thirty-Four First Grade Subjects.

VII.Weight in Pounds of Thirty-Four First Grade Children at Three Different Periods of the School Year, and Gain in Pounds.

IX. Height in Inches of Thirty-Four Flrst Grade Children at Three Different Periods of the School Year, and Gain in Inches.

X. Occupation of Fathers of Thirty-Four First Grade Pupils and liumber of Fathers in each Classification.

XI. Occupation of Mothers of Thirty-Four First Grade Pupils and Number of Mothers in each Classification.

XII. Social-Emotional Readiness as observed by Teacher of Thirty-Four First Grade Pupils.

XIII. The Subtest Scores and Average Grade Placement of Thirty-Four First Grade Pupils obtained from the Jietropolitan Achlevement Test administered on liay 5, ].952. 
Figure

I. First Choice of the Boys for Friends who they would like to have for their Partner for the Day. (october)

II. First Cholce of the Girls for Friends who they would like to have for their Partner for the Day. (october)

III. First Choice of the Subjects for Friends who they would like for thelr Partner charted Boys and Girls together. (october)

IV. First Choice of the Boys for Friends who they would like to have at their Party. (January)

V. First Cholce of the Girls for Friends who they would like to have at their Party. (January)

VI. First Choice of the Subjects for Friends who they would like to have at their Party. (January)

VII. First Choice of the Boys for Friends who they would like to have as Guests for Dinner. (llay)

VIII.First Choice of the Girls for Friends who they would like to have as Guests for Dinner. (Hay)

IX. First Cholce of the Subjects for Friends who they would like to have as Guests for Dinner. (May) 
CHAPTER I

THE PROBLEM AND ITS SCOPE 


\section{CHAPTER I}

\section{INTRODUCTION}

Statement of the Problem. For many years educators have felt there were too many failures in the first grade. Children enter school on the basis of having reached a Chronological age of six years on or before December 30 . Entrance into the first grade, as is generally understood by the public, means that a child is ready to begin reading. There are many factors which are related to a child's success in reading. For example, all children come to school with different backgrounds of experience, as well as different abllities. Some have traveled extensively, others may not have been more than ten miles away from their homes. Some children will have shared books and stories with their parents; others come from homes where little or no reading is done.

Also the relationship of various physical factors to abllity to read are everywhere apparent. Among those most Prequently found are inability to see or hear well. If a child has poor vision, he cannot be expected to get clear visual images of words, and will have difficulty in learming the words. Other physical factors less influential in learning to read are speech defects and recurring 11 linesses. 
Not all children who enter school have had wise and consistent parental discipline. Many have had over-solicItous parents and are far too dependent. Others have been constantly nagged and chastised and so have had little chance of becoming well adjusted children. These chlldren will be so immature emotionally that they will be poorly equipped to adjust to so new and difficult an experience as formal reading instruction.

Many children entering school have had no duties at home. They have not been taught to finish a task once started, and so on entering school their attention span is not long enough for direction for formal instruction. Jefferson County, in order to take care of the children who are too immature for regular first grade work, has an intensive Reading Readiness program. The inmature children are termed Junior Primaries and are kept in that group for their first year in school. These children are not termed fallures and are promoted to first grade at the end of the year. This program has not proved entirely satisfactory, since parents feel that the child has failed if he does not learn to read during the first year in school.

Some teachers belleve that if a child is to be successful in the first grade, he should have a mental age of at least six years, five months. He must be able to 1isten. This implies the ability to look at, to listen to, 
and to concentrate upon what is being taught. He must be able to follow directions, and to handle the usual classroom equipment, such as crayons, pencils, paper, scissors, and other materials. Ability to work in a group as a working member and not as a disturbing element is important. He should be independent in taking care of his person and belongings, and he should have a real desire to learn to read. The purpose of this paper was to obtain by a systematic study of thirty-four first graders the relationship of SocialEmotional maturity to learning achievement.

HYPOTHESIS: Children who are expected to learn to read because of Chronological age and Mental age may not succeed in learning to read because of the lack of SocialEmotional readiness. 


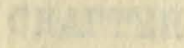

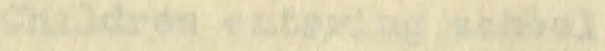

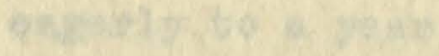

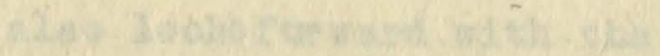

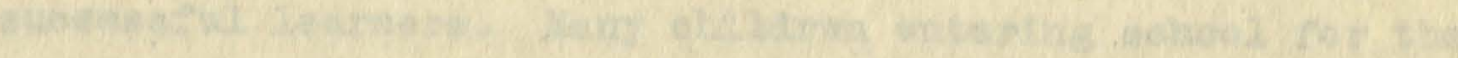

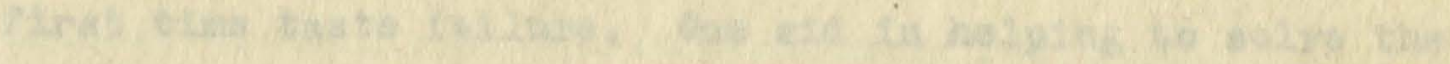

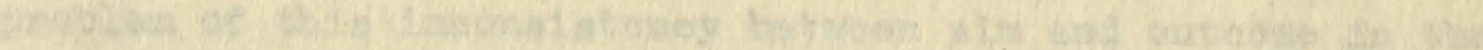

CHAPTER II

(4)

REVIEW OF THE IITERATURE

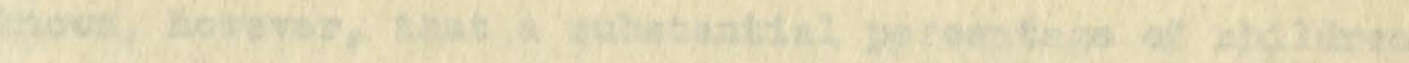

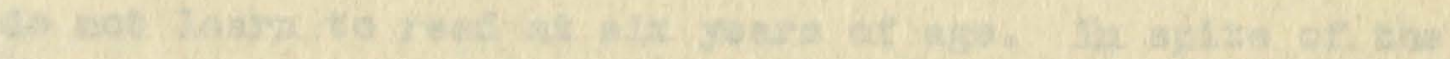

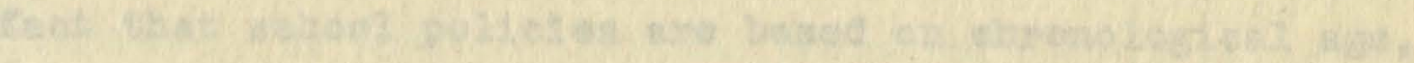

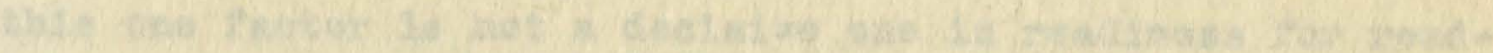


CHAPTER II

REVIEW OF THE LITERATURE

Children entering school in September look forward eagerly to a year of successful school work. The teacher also looks forward with the hope that the children will be successful learners. Many children entering school for the first time taste failure. One aid in helping to solve the problem of this inconsistency between aim and outcome in the first year is to ascertain when the child is ready to enter school.

The chronological age of the child is used as the chief basis for admission to the first grade. It is well known, however, that a substantial percentage of children do not leam to read at six years of age. In spite of the fact that school policies are based on chronological age, this one factor is not a decisive one in readiness for reading. Chronological age should be used only as a gulde in assignment of children to classrooms and not as a criteria for readiness for formal reading instruction.

Research data indicate that with a typical eirst grade program children less than $s 1 x$ years and three months to six years and six months do not succeed as well as older children. The child less than six, unless of above average

1. Betts, Emmett Albert. Foundat1ons of Reading Instruction. New York: American Book Company, 1946. ppo 119-12I. 
intelligence, tends to fail. The progress made by average children over six and a half years is overwhelmingly more satisfactory.

Children under six years of age with no more than average ab1lity have been taught to read with fair success, but educators agree that no child needs to learn so early, that his development is safe guarded by a well-rounded activity program, and that learning results with less strain and effort when reading instruction is postponed. Betts ${ }^{3}$ says that children who are admitted to school with chronological ages considerably below six years and have normal intelligence or less do not have as much chance of success with reading activities as do older pupils. He says that some children at the age of five might give superfor performance on tests of mental readiness for reading and yet be proved not physically ready and in need of social adjustment. He advises that the years before six should be spent in developing into a wholesome social being and in building a rich background of experience. Differences of a few months have been proved to be significant at these early 4 years.

Several studies based on first and second grade achievement have indicated that the majority of fallures were among those children who entered Grade One too early.

2. H1lareth, Gertrude. Iearning the Three R's. Minneapolis - Nashville -
lishers, Inc. pp. 135-145.

3. Betts, op. c1t., p. 112-117.

4. Hildreth, op. cit., p. 13. 
In March 1934 the school system in Summit, New Jersey made a. study based on fourth grade achievement, as grade four is the grade in which many chiloren have difficulty. This study was based on one group of twenty-eight children who entered grade one before they were chronologically six years of age, and another group of thirty-nine children who entered when they were chronologically between six years and six years and four months. From the dats collected as a result of this study it was found that a child who is chronologically between six years old and $s 1 x$ years and four months old, other factors being equal, will be practically certain to succeed in school.

Several surveys have been made by educators to determine the chronological age that first grade teachers think best for entrance to first grade. In a survey conducted by Carmichae ${ }^{6}$, School superintendent of Loulsville, 823 or sixty-eight per cent of the first grade teachers in his system favored six as the entrance age for children in school, 246 or twenty per cent favored f1ve or five and a half, and 144 or twelve per cent, favored six and a half or seven. This Indicates that those who work most closely with the children concerned are strongest in favoring six as the entrance age.

Young 7 conducted a survey for the Association of

5. Bigelow, Elizabeth B. "School Progress of Underage Chlldren", Elementary School Journal, Vol. 35, September 1934. pp. $186-192$.

6. The Cour1er-Journel. December 15, 1951.

7. Letter from Miss Arline Young, Covington, Kentucky to Mrs. Suda Butler, January 2, 1952. 
Supervision and Curriculum Development in which 225 questionnaires were sent to first grade teachers in Kentucky. It was found that eighty-one favored an entrance age of $s 1 x$ years and $s 1 x$ months and ninety-eight first grade teachers thought that the children should be $s 1 x$ years and six months old before recelving formal reading instruction.

Some educators belleve that the mental age is the criteria for entrance to first grade. Bond 8 said that a mental age of six years and six months was the necessary mental age for beginning instruction and therefore that instruction should be delsyed for any given child until he had reached that age. A mental age of six years and $s i x$ months may be interpreted as the mental level of an average child of six years and six months of age chronologically. There were two studies made during 1928-1930 in the Winnetka, Illinols school. 9 The investigators were concermed with two questions: What relationship existed between mental age and reading achievement? and What relationship existed between 1ntelligence quotient and reading achievement?

The first study involved 141 children for one semester. For the first study an intelligence test was given and reading progress was measured by the number of steps each

\footnotetext{
8. Bond, Guy L. \& Eva. Teaching the Child to Read. New York: The Mclililen Company. pp. 23-26.

9. M. V. Morphet and C. Washburne. "When Should Children Begin to Read?" The Elementary School Journal, XXXI, March 1931. pp. 496-502.
} 
pup1l had completed by February. In this study there was noted that very little, if any, progress was made by those children with mental ages below six years, but that the increase in percentage of success rises sharply at the mental age of $\mathrm{six}$ and one half.

The second test made the following year involved 100 children for one year. For this study a test was given to determine mental ages, and an oral reading check test and sight word list were used to measure reading progress. From this study it was found that the percentage of children makIng satisfactory reading progress rose sharply at the mental age of about $s 1 x$ years and $s 1 x$ months.

Responsibility was placed on the teacher by Gates 10 . He pointed out that the important thing was probably not the mentel test score of the child, but the type of educational program in which he was participating. In Gates' study, chlldren of mental ages above flve years had reasonable success in reading where skillful teachers, provided with a considerable amount of reading materials, gave individual attention to the pupils. On the other hand, another group, where the quality of instruction and material was not as good, required a mental age a full year in advance of that used in the first group for reading success. In other words, the important thing was not the mental age of the child, but the quality of teaching and instructional materials, especially

10. Gates, Arthur I. The Necessary Mental Age for Beginning Reading. Elementary School Journal, Vol. 37, pp. 497-508, Tarch 1937 . 
with reference to their adaption to the needs of the individual child. The program, not the mental test score, is the thing.

McKee ${ }^{11}$ was in accord w1th the belief of Gates. H1s belief was that teachers must make definite provisions for stimulating and fostering the child's development for reading readiness through a well developed plan of readiness instruction.

Most of the educators did not stress the importance of all the factors necessary for reading readiness, since they generally agreed that readiness for reading was a condition in which several factors played an important part. All agreed that a mental age of six and one half did not necessarily insure success in reading. The mental test was valuable only to indicate differences within a class, and should be used only to provide a basis for adapting methods and materials to bring about maximum learning. Reading Readiness tests were found to be of value but not to be used as a sole criteria for beginning reading instruction. 12 A summary of factors necessary to readiness for readIng was made into a check l1st by Russell13. Physical

II. VCKee, Paul. The Teaching of Reading in the Elementary School. New York 1948, Houghton Miflin Co. pp. 142-146.

12. Whitty, Paul. Reading in Modern Education. Boston: D. C. Heath and c0., 1941. pp. 57-61. 13. Russe11, Dav1d M. Children Learm to Read. Boston: Ginn and Co., 1941. pp. 126-128. 
readiness such as good vision, proper hearing, average general health and mot or coordination were found necessary to success in reading. Social-emotional readiness such as cooperation, independence, listening and adjustments were of equal importance to mental maturity. The child's ability to speak clearly, general interest in reading and knowledge of certain relational words such as up and down, top and bottom, big and little were also factors to be considered. Therefore, when a child had developed a number of qualities, he was ready to read. If he had the ability to see and hear well, was able to speak clearly and had a certain ease with language and a workable vocabulary, plus a wide variety of experiences, he was emotionally stable and had proper muscular coordination, he would usually succeed in learning to read. 14

14. W1lshinger, D. K. Summary of Reading Readiness Research, "Educat1onal Admini stration and Supervision", XXXIV, October 1948, pp. 372-376. 


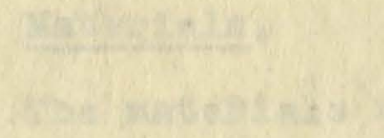

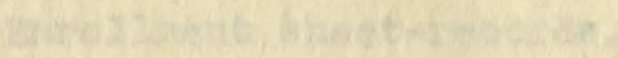

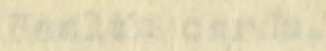

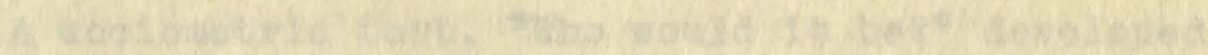

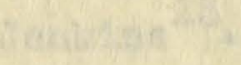

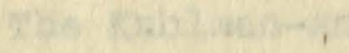

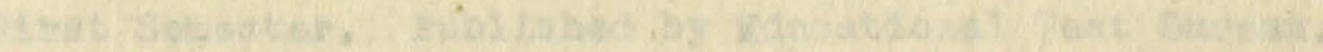

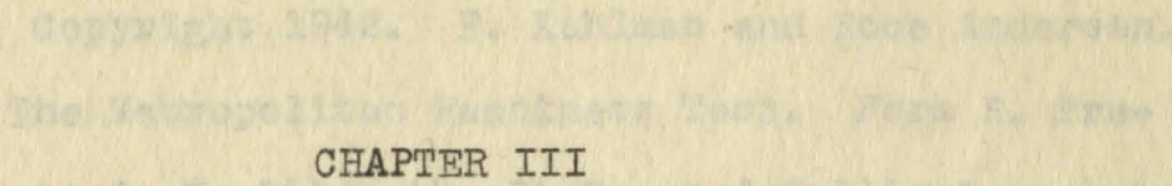

CHAPTER III

\section{METHODS}

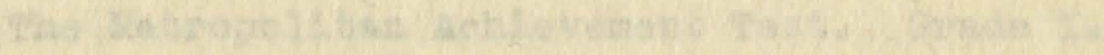

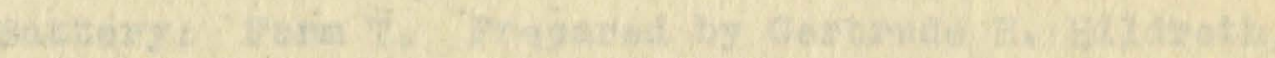

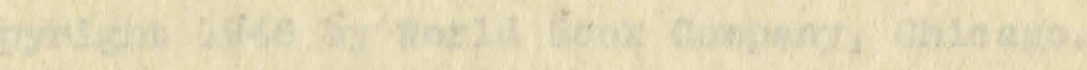

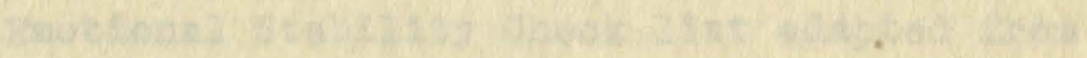




\section{CHAPTER III}

\section{METHODS}

\section{Materials.}

The materials used in this study were:

Enrollment sheet-records.

Health cards.

A sociometric test, "Who would it be?" developed by Gladys Jenkins ${ }^{15}$.

The Kuhlman-Anderson Intelligence Test. Grade I, First Semester. Published by Educational Test Bureau. Nashville, Copyright 1942. F. Kuhlman and Rose Anderson. The Metropolitan Readiness Test. Form R. Prepared by Gertrude H. Hildreth, Ph.D., and Nellie L. Griffiths, M.A. Copyright 1949 by World Book Company, Chicago.

The Netropolitan Achievement Test. Grade I. Primary I Battery: Form T. Prepared by Gertrude H. Hildreth, Ph.D. Copyright 1946 by World Book Company, Chicago.

Emotional Stability Check list adapted from Russeli ${ }^{16}$.

The enrollment sheets were completed by the parents on the entrance of the child in school. The following information was obtained from them: Name, birthdate of child; name,

15. Jenkins, Gladys, Helen Schacter, and William S. Bauer, These Are Your Children. (Chicago: Scot, Foresman, 1949) p. 163 . 16. Russell, David, Children Learn to Read. Boston: Ginn and Company. p. 126 . 
address and occupation of parents; number of children in home and ages; number of children who attended Kindergarten;

Wother's maiden name; and broken homes.

On the health card was recorded the doctor's report of examination made at school and recommendations; also information pertaining to childhood diseases and inoculations, which was secured from a questionnaire sent to the parents at the beginning of the school year; teacher's report on vision, height and weight.

The Kuhlman-Anderson Intelligence Test yields two scores, the mental age and the intelligent quotient. This test was used as a means of determining the child's mental age, and of comparing the mental maturity with others in the class.

The Metropolitan Readiness Test is designed to measure the traits that contribute to the child's readiness for reading. This test was used as a means of determining those subjects who were ready for formal reading instruction in so far as the test measured. It was not used as the sole basis for beginning formal instruction.

The Metropolitan Achievement Test was designed to test achievement in word meaning, word recognition, vocabulary and comprehension. This test was used to help substantiate the supposition that subjects who are old enough chronologically, have average intelligence and are social-emotionally adjusted will have success in learning to pead their first 
Jear in school.

The Soclometric Test contrined hypothetical situations In which chilaren state their preference for companions in given situations. The sociograms were first charted for the nineteen boys and fifteen girls separately, then charted together as a group.

The general observation check list developed by Russell 17 was used to locate the emotionally unstable subjects in the study. This study was also used to determine those subjects who were ready for formal reading instruction.

The case studies of the four subjects who were placed in the Junior Primary Group were used to show why they were not given formal reading instructions their first year in school.

\section{Subjects:}

The subjects used in this paper were a group of fifteen girls and nineteen boys in a first grade in a Jefforson County school. The ages ranged from five years, eleven months to seven years, three months. The I.Q. of the subjects ranged from ninety-six to one hundred and twenty-three.

\section{Techniques:}

The Kuhlman-Anderson Intelligence Test and The Metropolitan Readiness Test were administered in October 1951. The Metropolitan Achievement Test was administered in May 1952. 
Soclograms were administered in october 1951, January 1952, and May 1952.

Observations for the emotional stability check list were made during october 1951. 
CHAPTER IV

INFORMATION ON THIRTY-FOUR FIRST GRADE SUBJECTS 
CHAPTER IV

INFORMATION ON THIRTY-FOUR

FIRST GRADE SUBJEOTS

The data given in Table I shored that the chronological age of the subjects ranged from flve years, eleven months to seven years, three months in September 1951. Pup11 No. 31 and pup1l No. 34 whose chronological ages were over seven had been in school the previous year. The median chronological age was $s 1 x$ years, f1ve months, while the mean was $s i x$ years, five months with a standard deviation of 4.1 months. There was a range of seventeen months on the test.

Bighteen of the subjects had chronological ages less than $s i x$ years, $s 1 x$ months. Fifteen of the subjects had chronological ages of $s 1 x$ years, six months or over.

The range in mental ages was from six jears, three months, to seven years, four months. The range of the mental ages was not as great as the range in chronological age. The median mental age was six years, elght months; the mean was six years, seven months with a standard deviation of 3.13 months. Of the twelve children who had a mental age of seven years or older, five had a chronological age of less than six years, six months and seven a chronological age of over six jears, six months.

The intelligence quotients ranged from ninety-six to one hundred twenty-three. There was a range of twenty-seven on the test. The mean was 108.17 with a standard deviation 


\section{TABIE I}

THE CHRONOIOGICAL AGES, MBNTAL AGES, AND INTELIIGENCE QUOTIENTS OF THIRIY-FOUR FIRST GRADE PUPIIS OBTAINED FROM THE KULHMAN-ANDERSON INTELLIGENCE TEST ADMINISTERED IN OCTOBER 1951

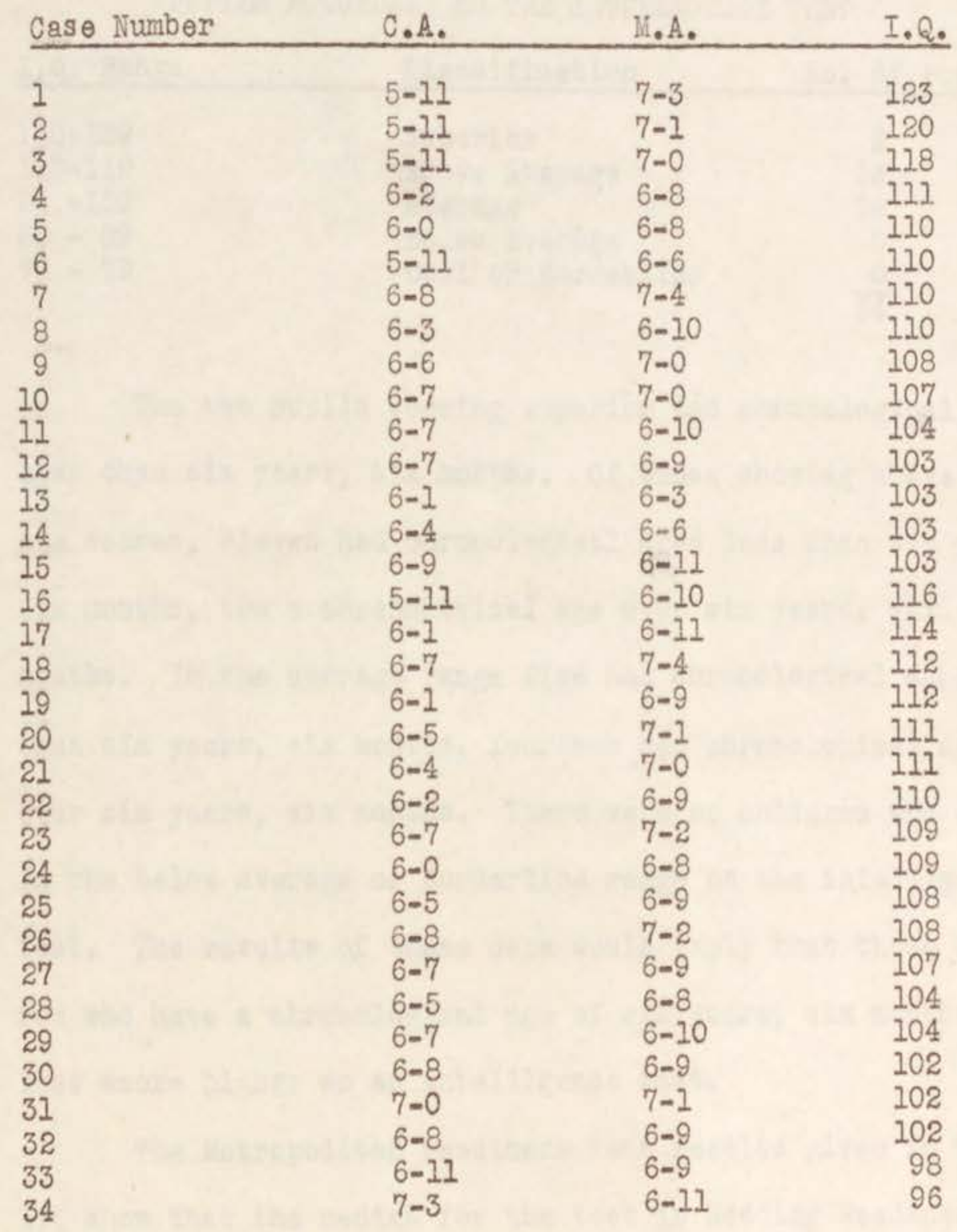


of 5.85. Table No. II shows the classification of the thirtyfour pupils according to the test.

\section{TABIE II}

CLASSIFICATION AND RANGE OF THIRTY-FOUR FIRST GRADE PUPIIS ACCORDING TO THE INTELLIGENCE TEST

I.Q. Range

120-129

$110-119$

$90-109$

$80-89$

$70-79$
Classification

Superior

Above Average

Average

Below Average

Dull or Borderline
No. of Pupils

2

13

19

0

$\frac{0}{34}$

The two pupils scoring superior had chronological ages less than six years, six months. Of those showing above average scores, eleven had chronological ages less than six years, six months, two a chronological age over six years, six months. In the average range five had chronological ages less than six years, six months, fourteen had chronological ages over six years, six months. There were no children who scored in the below average or borderline range on the intelligence test. The results of these data would imply that those children who have a chronological age of six years, six months or less score higher on an intelligence test.

The Metropolitan Readiness Test results given in Table III show that the median for the test in Reading Readiness was fifty-nine. The mean was 58.56 with a standard deviation of 5.84. There was a range of seventeen on the test. 


\section{TABLE III}

RESULTS OF METROPOIITAN READINESS TEST ADMTNISTERED TO THIRTY-FOUR FIRST GRADE PUPIIS OCTOBER 18, 1951

\begin{tabular}{|c|c|c|c|c|}
\hline Case Number & 1 & 2 & 3 & Classification \\
\hline $\begin{array}{l}1 \\
2 \\
3 \\
4 \\
5 \\
6 \\
7 \\
8 \\
9 \\
10 \\
11 \\
12 \\
13 \\
14 \\
15 \\
16 \\
17 \\
18 \\
19 \\
20 \\
21 \\
22 \\
23 \\
24 \\
25 \\
26 \\
27 \\
28 \\
29 \\
30 \\
31 \\
32 \\
33 \\
34\end{array}$ & $\begin{array}{l}64 \\
59 \\
64 \\
58 \\
51 \\
49 \\
58 \\
62 \\
59 \\
60 \\
62 \\
63 \\
38 \\
50 \\
59 \\
60 \\
59 \\
64 \\
54 \\
53 \\
64 \\
60 \\
65 \\
50 \\
58 \\
59 \\
65 \\
62 \\
59 \\
55 \\
64 \\
58 \\
61 \\
65\end{array}$ & $\begin{array}{l}30 \\
28 \\
34 \\
27 \\
22 \\
15 \\
32 \\
33 \\
30 \\
30 \\
32 \\
25 \\
25 \\
21 \\
25 \\
25 \\
32 \\
29 \\
25 \\
29 \\
34 \\
28 \\
31 \\
17 \\
24 \\
29 \\
31 \\
23 \\
27 \\
29 \\
30 \\
26 \\
33 \\
30\end{array}$ & $\begin{array}{l}94 \\
87 \\
98 \\
85 \\
73 \\
64 \\
60 \\
95 \\
89 \\
90 \\
94 \\
88 \\
63 \\
71 \\
84 \\
85 \\
91 \\
91 \\
79 \\
82 \\
98 \\
88 \\
96 \\
67 \\
82 \\
88 \\
96 \\
85 \\
86 \\
84 \\
94 \\
84 \\
94 \\
85\end{array}$ & $\begin{array}{l}\text { Superior } \\
\text { High Normal } \\
\text { Superior } \\
\text { High Normal } \\
\text { Average } \\
\text { Low Normal } \\
\text { Iow Normal } \\
\text { Superior } \\
\text { High Normal } \\
\text { Superior } \\
\text { Superior } \\
\text { High Normal } \\
\text { Low Normal } \\
\text { Average } \\
\text { High Normal } \\
\text { High Normal } \\
\text { Superior } \\
\text { Superior } \\
\text { Average } \\
\text { High Normal } \\
\text { Superior } \\
\text { High Normal } \\
\text { Superior } \\
\text { Average } \\
\text { High Normal } \\
\text { High Normal } \\
\text { Superior } \\
\text { High Normal } \\
\text { High Normal } \\
\text { High Normal } \\
\text { Superior } \\
\text { High Normal } \\
\text { Superior } \\
\text { High Normal }\end{array}$ \\
\hline & $\begin{array}{l}\text { Test } 1 \\
\text { Test } 2 \\
\text { Test } 3\end{array}$ & \multicolumn{3}{|c|}{$\begin{array}{l}\text { Reading Readiness } \\
\text { Number Readiness } \\
\text { Total Readiness }\end{array}$} \\
\hline
\end{tabular}


Table IV shows the classification of the thirty-four puplis according to the test.

\section{TABLE IV}

CLASSIFICATIONS ON THE METROPOLITAN READING READINESS TBST OF THIRTY-FOUR FIRST GRADE PUPILS LISIBD IN TABIB III

Classification

Superior

High Normal

Average

Low Normal

Poor Risk
Pupils

14

12

7

1

$\frac{0}{34}$

Of the fourteen children ranking superior on the test, five had chronological ages of less than six years, six months, nine chronological ages of more than six years, six months. Three of the children scoring superior on the test were repeaters in the first grade. Of the twelve showing high normal on the test, six had chronological ages less than six years, six months, six had chronological ages more than six years, six months. In the average group, six children had chronological ages less than $s i x$ jears, six months, one a chronological age of more than six years, six months. The one child scoring in the low normal group had a chronological age of six years, one month. The results of this test would indicate that in this class the children who scored highest were those children who had a chronological age of six years, six months or over. 
As indicated in Table III, the range in the liumber Readiness Test scores was nineteen. This range was two points more than in the Reading Readiness Test scores. The mean of this test was 27.67 with a standard deviation of 4.53 . Of the thirty-four children who were given this test, thirty-two scored superior, one high normal, and one average. The child scoring in the high normal range had a chronological age of six years, one month; the child scoring in the average range had a chronological age of six years.

The total readiness results as given in Table III show that the median for the test was elghty-six with a range in scores of seventeen points. This is the same range found in both the Intelligence Test and Reading Readiness Test. The mean for total readiness was 85.06 with a standard deviation of 10.22. Table $V$ shows the classification of the thirty-four first grade pupils according to total readiness.

\section{TABLE V}

FREQUENCY DISTRIBUTION OF THE THIRTY-FOUR FIRST GRADE PUPILS ON TOTAL READINESS

\section{Classification}

Superior High Normal

Average

Low Normal

Poor Risk
Pup11s

12

15

4

3

$\frac{0}{34}$

of the twelve children ranking superior on the test, five had chronological ages less than six years, six months, 
seven chronological ages more than six years, six months. In the high normal classification, seven children had chronological ages of less than six years, six months, elght chronological ages more than six years, six months. All four of the children in the average classification had chronological ages less than six years, six months. Two children in the low normal group had chronological ages less than six years, six months, one a chronological age more than six years, six months. The results of this test would indicate that children with a chronological age of six years, six months or more score higher in total readiness.

The results shown in Table I and Table II would indicate that all the subjects studied would have success in learning to read their first year in school. But intelligence and reading readiness are just two of the many factors which determine a child's ability to learn to read. Home background, physical health and emotional stability of the subjects are important factors in determining a subject's readiness for learning.

\section{TABLE VI}

A TABULATION OF THE CHILDHOOD DISEASES OF THIRTY-FOUR FIRST GRADE SUBJECTS PRIOR TO ENTERTNG AND

AFNER ENTERING SCHOOL

\begin{tabular}{lcr} 
Childhood Diseases & First Grade & Before Sch \\
\cline { 3 - 4 } Chickenpox & 5 & 13 \\
Measles & 11 & 13 \\
Mumps & 0 & 8 \\
Scarlet Fever & 1 & 2 \\
Polio & 0 & 1
\end{tabular}


The childhood diseases listed in Table VI show that more children had measles than any other disease. There were eleven cases during the school year. Chickenpox was the next highest. Not many have had mumps, scarlet fever or polio. The pollo case was dismissed from Kosair Hospital in August 1951 after a year's stay. Although he wore braces and was hindered in walkIng and playing, he was a bright child with a C.A. of six years, eight months, M.A. of seven jears, two months and I.Q. of 107.

Six subjects had their tonsils removed during the year. They were absent two weeks. Five of them were average or above in their work, and the tonsillectomy did not hinder their progress. The other had already been placed in the Junior Primary Group before the time of the tonsillectony.

Flu or virus infection was responsible for the most absences from school. However, those infected with these diseáses were average or above in their work, and the parents helped them with their school work so they were not hindered in their progress in school by the diseases.

There was only one subject in the group studied who was absent often because of 1llness. These absences ald not hinder her progress to any great extent. This was probably due to the fact that she had a C.A. of six years, nine months, M.A. of six years, eleven months, with an I.2. of 103.

There were only two subjects who wore glasses in the group. In both cases the glasses were being used to strengthen weak muscles in the ejes of the subjects. Vision was normal 
with the glasses. All the other subjects studied had twentytwenty or twenty-thirty vision, which is accepted as normal vision.

Table VII shows that five subjects had good teeth. There were twenty-three subjects who had one or more cavities. There were only six subjects who had teeth in poor condition. Fourteen of the subjects studied had never been to a dentist. Ten made regular visits to the family dentist.

\section{TABLE VII}

RESULTS OF DENTAL INSPECTION OF THIRTY-FOUR FIRST GRADE SUBJECTS

\section{Classification}

Good Teeth

One or more cavities

Teeth in poor condition
Number

5

23

$\frac{6}{34}$

Dental slips were given to the subjects to be taken to their family dentist and returned to the teacher when the defects were corrected. Of the six pinik slips sent home, which Indicated teeth in poor condition, five were returned signed by the family dentist. The one not returned was from the poorest family among the subjects. The parents indicated that they would have the work done as soon as possible. Eighteen of the blue slips were returned. These slips indicated teeth with one or more cavities. The remaining five were not returned and no reason was given for not taking the subject to the family dentist. The attention given the dental slips by the parents was 
unusual. As a result of the visit to the dentist, the condition of the teeth of the subjects could not have interfered to a great extent with their learning to read.

Table VIII shows that in October the subjects in this study ranged in wolght from thirty-nine pounds to sixty-six pounds. In Fobruary the range was from forty-two pounds to sixty-five pounds. All of the subjects showed a gain in weight from October to February with the exception of Pupil No. 8. The average gain for this period was three-plus pounds. In May the range was from forty-two pounds to sixty-eight pounds. Four subjects lost one pound during the period from February to May. This was probably due to measles, as those subjects had it during that period. Fifteen subjects showed no gain during this period. Two subjects gained four pounds, five gained two pounds, and eight gained one pound. There was not as much gain during the period from February to Nay as there had been from October to February.

The mean gain in weight for the year was 4.- pounds. Three subjects gained nine pounds, three gained six pounds, seven gained flve pounds, three galned four pounds, four gained three pounds, nine gained two pounds, one gained one pound, and one made no gain in weight.

The normal gain in weight of children of this chronological age is from three to six pounds a jear. Table VIII shows that eighteen of the subjects made as much gain during the period of study as they should have made during the entire 
year. The other sixteen gained as much as is usual as this study was only for a perlod of eight months. The above data seem to indicate that the subjects in this class were normal or above normal in their growth in weight.

\section{TABLE VIII}

WBIGHI IN POUNDS OF THIRTY-FOUR FIRST GRADE CHILDREN AT THREE DIFFERENT PERIODS OF THE SCHOOL YEAR, AND GAIN IN POUNDS

\begin{tabular}{|c|c|c|c|c|c|c|}
\hline Pup11 & $\begin{array}{l}\text { Weight } \\
\text { in } \\
\text { oct. }\end{array}$ & $\begin{array}{c}\text { Weight } \\
\text { in } \\
\text { Fob. }\end{array}$ & $\begin{array}{l}\text { Gain } \\
\text { Oct. } \\
\text { to } \\
\text { Feb. }\end{array}$ & $\begin{array}{c}\text { Weight } \\
\text { in } \\
\text { May }\end{array}$ & $\begin{array}{l}\text { Gain } \\
\text { Feb. } \\
\text { to } \\
\text { May } \\
\end{array}$ & $\begin{array}{l}\text { Gain } \\
\text { oct. } \\
\text { to } \\
\text { llay }\end{array}$ \\
\hline $\begin{array}{r}1 \\
2 \\
3 \\
4 \\
5 \\
6 \\
7 \\
8 \\
9 \\
10 \\
11 \\
12 \\
13 \\
14 \\
15 \\
16 \\
17 \\
18 \\
19 \\
20 \\
21 \\
22 \\
23 \\
24 \\
25 \\
26 \\
27 \\
28 \\
29 \\
30 \\
31 \\
32 \\
33 \\
34\end{array}$ & $\begin{array}{l}49 \\
54 \\
39 \\
48 \\
40 \\
46 \\
40 \\
66 \\
46 \\
52 \\
53 \\
50 \\
44 \\
44 \\
48 \\
40 \\
58 \\
50 \\
46 \\
49 \\
48 \\
50 \\
50 \\
49 \\
44 \\
46 \\
42 \\
62 \\
44 \\
42 \\
55 \\
57 \\
49 \\
52\end{array}$ & $\begin{array}{l}56 \\
58 \\
42 \\
52 \\
43 \\
49 \\
42 \\
66 \\
50 \\
54 \\
56 \\
55 \\
46 \\
45 \\
50 \\
43 \\
60 \\
58 \\
48 \\
50 \\
52 \\
54 \\
60 \\
61 \\
46 \\
50 \\
44 \\
64 \\
48 \\
44 \\
60 \\
62 \\
54 \\
56\end{array}$ & $\begin{array}{r}7 \\
4 \\
3 \\
4 \\
3 \\
3 \\
2 \\
0 \\
4 \\
2 \\
2 \\
3 \\
5 \\
2 \\
1 \\
2 \\
3 \\
2 \\
8 \\
2 \\
1 \\
4 \\
4 \\
10 \\
12 \\
2 \\
4 \\
2 \\
2 \\
4 \\
2 \\
5 \\
5 \\
5 \\
4\end{array}$ & $\begin{array}{l}58 \\
57 \\
42 \\
54 \\
42 \\
51 \\
42 \\
66 \\
51 \\
54 \\
57 \\
55 \\
46 \\
46 \\
50 \\
45 \\
61 \\
59 \\
52 \\
50 \\
53 \\
54 \\
59 \\
61 \\
48 \\
51 \\
45 \\
68 \\
48 \\
44 \\
60 \\
62 \\
54 \\
54\end{array}$ & $\begin{array}{r}2 \\
-1 \\
0 \\
2 \\
-1 \\
2 \\
0 \\
0 \\
1 \\
0 \\
1 \\
0 \\
0 \\
1 \\
0 \\
2 \\
1 \\
1 \\
4 \\
0 \\
1 \\
0 \\
-1 \\
0 \\
2 \\
1 \\
1 \\
1 \\
4 \\
0 \\
0 \\
0 \\
0 \\
0 \\
-2\end{array}$ & $\begin{array}{r}9 \\
3 \\
3 \\
6 \\
2 \\
5 \\
2 \\
0 \\
5 \\
2 \\
4 \\
5 \\
2 \\
2 \\
2 \\
5 \\
3 \\
9 \\
6 \\
1 \\
5 \\
4 \\
9 \\
12 \\
4 \\
5 \\
3 \\
6 \\
4 \\
2 \\
5 \\
5 \\
5 \\
2\end{array}$ \\
\hline
\end{tabular}


Table IX shows that in october the subjects in this study ranged in height from forty-four inches to fifty-two inches. In February the range was from forty-five inches to fifty-four inches. Two subjects showed no gain in height from october to February. Twenty-eight showed a gain of one inch, and four showed a gain of two inches. In llay the range in helght was from forty-five inches to fifty-four inches. There was not as much gain from February to llay as there had been from october to February. All the subjects showed a gain in height of as much as one inch for the period studied. Four subjects gained two inches and six subjects gained one and one-half inches or more.

In considering the gain in height and weight of children, all authorities are in agreement that children entering school are in a slow stage of growth. The normal gain in height is from two-and-a-half to three inches a year. Since the figures shown in Table IX are for eight months, two-thirds of the above amount would be considered normal. The individual records show that the large majority of the subjects gained in height normally for the period studied.

Physical health of the subject is important to the extent that good health may enable him to learn to read while poor health may affect his success in learning to read. From a study of the data concerning the health of the subjects, there seems to be nothing to indicate that 111 health prevented any of the subjects from learning to read. 


\section{TABIE IX}

HEIGHT IN INCHES OF THIRTY-FOUR FIRST GRADE CHILDREN AT THREE DIFFERENT PERIODS OF THE SCHOOL YEAR AND GAIN IN INCHES

\begin{tabular}{|c|c|c|c|c|c|c|}
\hline Pup11 & $\begin{array}{l}\text { Height } \\
\text { in } \\
\text { oct. }\end{array}$ & $\begin{array}{c}\text { Height } \\
\text { in } \\
\text { Feb. }\end{array}$ & $\begin{array}{c}\text { Gain } \\
\text { Oct. } \\
\text { to } \\
\text { Feb. }\end{array}$ & $\begin{array}{l}\text { Height } \\
\text { in } \\
\text { May }\end{array}$ & $\begin{array}{c}\text { Gain } \\
\text { Feb. } \\
\text { to } \\
\text { May }\end{array}$ & $\begin{array}{c}\text { Gain } \\
\text { oct. } \\
\text { to } \\
\text { May }\end{array}$ \\
\hline $\begin{array}{l}1 \\
2 \\
3 \\
4 \\
5 \\
6 \\
7 \\
8 \\
9 \\
9 \\
10 \\
11 \\
12 \\
13 \\
14 \\
15 \\
16 \\
17 \\
18 \\
19 \\
20 \\
21 \\
22 \\
23 \\
24 \\
25 \\
26 \\
27 \\
28 \\
29 \\
30 \\
30 \\
31 \\
32 \\
33 \\
34\end{array}$ & $\begin{array}{l}47 \\
49 \\
46 \\
45 \\
44 \\
44 \\
44 \\
51 \\
49 \\
48 \\
48 \\
48 \\
47 \\
46 \\
48 \\
45 \\
51 \\
51 \\
47 \\
50 \\
48 \\
50 \\
50 \\
50 \\
48 \\
48 \\
46 \\
47 \\
48 \\
46 \\
52 \\
50 \\
47 \\
48\end{array}$ & $\begin{array}{l}48 \\
50 \\
47 \\
47 \\
45 \\
46 \\
45 \\
52 \\
49 \\
49 \\
49 \\
49 \\
48 \\
46 \\
49 \\
46 \\
52 \\
52 \\
48 \\
51 \\
49 \\
51 \\
51 \\
51 \\
49 \\
50 \\
47 \\
48 \\
49 \\
47 \\
54 \\
51 \\
48 \\
49\end{array}$ & $\begin{array}{l}1 \\
1 \\
1\end{array}$ & $\begin{array}{l}48 \\
50 \\
47 \\
47 \\
45 \\
46 \\
45 \\
52 \\
50 \\
49 \\
49 \\
49 \\
48 \frac{1}{2} \\
47 \\
49 \\
46 \\
52 \\
52 \\
48 \\
51 \\
49 \\
51 \\
51 \\
51 \\
49 \frac{1}{2} \\
50 \\
47 \frac{1}{2} \\
48 \\
49 \\
47 \\
54 \\
51 \frac{1}{2} \\
48 \frac{1}{4} \\
49 \frac{1}{2}\end{array}$ & 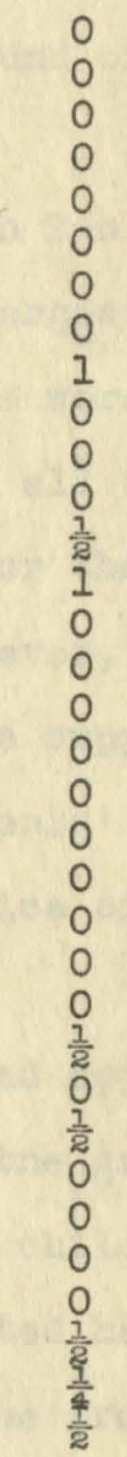 & 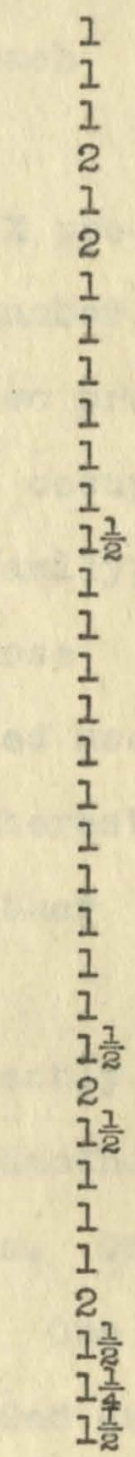 \\
\hline
\end{tabular}


A knowledge of the home from which the child comes is another factor in readiness for learning. Physchologists and educators agree that the first $s 1 x$ years of a chlld's 11 fo are fundamental in shaping his character and personality traits. There is a great variation in the abilities of children as they enter school. Therefore, it is necessary for the teacher to know as much as possible about the home background of each child in order to understand him.

The occupation of the fathers as shown in Table X presents a large number of classifications. The largest number of the group were executives in industry. There were two professional men and seven were self-employed. In all the occupations 11sted, there seemed to be amplo income for the family, except possibly the two who were laborers. However, those chlliren from the laborers' homes had all of the supplies needed in school. This was probably due to the parents' interest In his child doing well in school at the sacriflce of other things.

There were only three working mothers, and apparently this presented no problem as in each situation the grandmother lived in the home, and was there to be with the children. Only one mother worked because her husband had deserted her. One of the others was separated from hor husband, but he provided amply for both the needs of the mother and her children. All the farilies represented in the group visited the school at some 
time during the year. All seemed equally interested in the progress of their children. The subjects from the higher income families did not score any higher on the Readiness Test or on the I.Q. Test than did the subjects from the lower income families.

\section{TABLE X}

OCCUPATION OF FATHERS OF THIRTY-FOUR FIRST GRADE PUPTIS AND NUIBER OF FATHERS IN EACH CLASSIFICATION

\begin{tabular}{lc} 
Classification & Numb \\
\cline { 2 - 2 } Electrician & 2 \\
Attorney & 1 \\
Maintenance & 3 \\
Plumber & 3 \\
Personnel & 1 \\
Engineer & 1 \\
Laborer & 2 \\
Mechanic & 3 \\
Mover & 1 \\
Palnter & 2 \\
Carpenter & 1 \\
Boiler Operator & 1 \\
Broker & 1 \\
Bxecutive & 5 \\
Foreman & 1 \\
Accountant & 2 \\
Physician & 1 \\
Contractor & 1 \\
Funeral Director & 1 \\
Milk Man & $\frac{1}{34}$ \\
\end{tabular}

Number

TABLE XI

OCCUPATION OF NOTHERS OF THIRTY-FOUR RTRST GRADE PUPILS AND NUMBER OF MOTHERS IN EACH CLASSIFICATION

Classification

Housewife

Tobacco examiner

Social worker

office manager

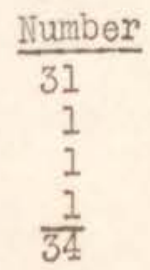


CHAPTER V

SOCIAL-EMOTIONAL READINESS OF THIRTY-FOUR

FIRST GRADE PUPIIS 


\section{CHAPTER V}

\section{SOCIAI-BIOTIONAL READINESS OP THIPTY-FOUR} PIRST GRADE PUPIIS

Probably the best way of detemining whether or not a child is ready to read is directed observation of the child's behavior in various situations in the classroom and on the playground. Social-emotional readiness was considered one of the most 1mportant factors in determining whether a child was ready to read. In determining social-emotional readiness, the teacher made an observation of her subjects for six weeks before starting formal reading instruction.

One of the factors of social-emotional readiness is cooperation. The teacher observed the subject at play, to see if he cooperated in playing games involving several children. The subject must be able to work in a group, content with the task he has been assigned, and he must be a good follower as well as a good leader.

\section{Independence is another factor in social-omotional} readiness. The subject should be able to take care of his own clothes. He should be able to work by himself without asking for help. The ability to find something else to do when he has finished some task is important in determining Independence.

Another factor in determining social-emotional readiness is sharing. The subject is observed to see if he shares materials without monopollzing their use. Does he bring toys 
or books from home that other children may use? Does he wait for his turn in play or when the teacher is checking the class's work?

The ablilty to listen is felt by some first grade teachers as the most important factor in determining socialemotional readiness. The subject must be attentive before receiving formal reading instruction. He should be able to listen to all of a story with evident enjoyment, so that ho can retell it or, at least, part of $1 \mathrm{t}$. He should listen to others without interrupting and he must be able to follow one or two simple directions.

Other things observed by the teacher and felt necessary for social-emotional readiness are termed in Table XII as adjustments. Under adjustments the teacher considered whether the subject could see a task such as drawing or preparing for an activity, or cleaning up, completed without becoming discouraged. Does he accept changes in the school routine quietly? Can he accept a certain amount of opposition or defeat without crying or sulking? Does he appear to be happy and well adjusted in his school work? And, can he meet strangers without unusual shyness?

All subjects entering the first grade in the school in which this study was made were given a Readiness Program for six weeks before formal instruction began. The teacher was usually able to bring those subjects to a place in socialemotional readiness that was necessary for learning, but some 
subjects will not reach that level during thelr first year in school.

Table XII shows the results of the social-emotional observations made of the thirty-four subjects used in this study in October 1951. When this observation was made the subjects had been in school for one month. At that time as shown in Table XII thirteen of the subjects were not ready for formal reading instruction as they did not rate satisfactory in the social-emotional criteria used. All of the thirteen not rating satisfactory in the social-emotional observation according to C.A., M.A. and I.Q. as shown in Table I should have been successful in learning to read their first year in school. Nine of those subjects after a longer readiness program were able to reach the level of social-emotional readiness which was necessary for learning, but four of the subjects were not to reach that level their first year in school. Those four were Pupil No. 5, No. 6, No. 14, and No. 24.

Pup11 No. 5 entered first grade in September 1951 with a C.A. of six years, six months. On the Reading Readiness Test she made a low normal score. Her Intelligence score on the Intelligence Test was 110. From the I.Q. score her mentaI age was found to be six years, eight months. The above factors would indicate that Pupil No. 5 would learn to read during her first year in school.

An investigation of the family background revealed that Pupil No. 5 was an only child who came from a home in which 


\section{TABLE XII}

SOCIAL-ENOTIONAL READINESS AS OBSERVED BY TEACHER OF THE THIRTY-FOUR FIRST GRADE PJPIIS

\begin{tabular}{|c|c|c|c|c|c|}
\hline Pupil & Co-operation & Independence & Sharing & Iistening & Adjustments \\
\hline 1 & F & P & F & $\mathrm{P}$ & $\mathrm{P}$ \\
\hline 2 & $F$ & $\mathrm{P}$ & F & $\mathrm{P}$ & $\mathrm{E}$ \\
\hline 3 & $F$ & G & $G$ & $\mathrm{~F}$ & F \\
\hline 4 & G & G & G & $G$ & G \\
\hline 5 & $P$ & $\mathrm{P}$ & P & P & P \\
\hline 6 & $\mathrm{P}$ & $\mathrm{P}$ & $\mathrm{P}$ & $\mathrm{P}$ & $\mathrm{P}$ \\
\hline 7 & G & G & G & G & G \\
\hline 8 & $\mathrm{~F}$ & $\mathrm{~F}$ & $\mathrm{~F}$ & P & $\mathrm{F}$ \\
\hline 9 & G & G & G & G & $G$ \\
\hline 10 & G & G & G & G & G \\
\hline 11 & G & G & G & G & G \\
\hline 12 & G & G & G & G & G \\
\hline 13 & P & $\mathrm{P}$ & $\mathrm{P}$ & $\mathrm{P}$ & $\mathrm{P}$ \\
\hline 14 & P & $\mathrm{F}$ & $\mathrm{F}$ & P & $\mathrm{F}$ \\
\hline 15 & G & G & G & G & G \\
\hline 16 & G & $\vec{F}$ & $\mathrm{~F}$ & G & G \\
\hline 17 & $G$ & F & $\mathrm{F}$ & F & $P$ \\
\hline 18 & $G$ & $G$ & G & $\mathrm{G}$ & $G$ \\
\hline 19 & $\mathrm{~F}$ & $F$ & F & $\mathrm{F}$ & F \\
\hline 20 & G & $\mathrm{F}$ & F & G & $G$ \\
\hline 21 & G & F & F & $F$ & G \\
\hline 22 & $F$ & F & F & $\mathrm{F}$ & $F$ \\
\hline 23 & $G$ & $G$ & $G$ & $\mathrm{~F}$ & F \\
\hline 24 & $\mathrm{P}$ & P & P & $\mathrm{P}$ & P \\
\hline 25 & F & P & P & $\bar{F}$ & P \\
\hline 26 & $G$ & G & G & $\mathrm{F}$ & F \\
\hline 27 & $G$ & $G$ & $G$ & $G$ & $G$ \\
\hline 28 & $\mathrm{~F}$ & $F$ & $F$ & $F$ & $F$ \\
\hline 29 & $G$ & $\mathrm{~F}$ & $\bar{F}$ & $G$ & F \\
\hline 30 & $F$ & $\mathrm{~F}$ & F & F & P \\
\hline 31 & $G$ & G & $G$ & $G$ & G \\
\hline 32 & G & G & G & $G$ & G \\
\hline 33 & G & $G$ & $G$ & $G$ & G \\
\hline 34 & $\mathrm{~F}$ & $G$ & $G$ & F & $G$ \\
\hline
\end{tabular}

\footnotetext{
G - Indicates Good

F - Indicates Fair

P - Indicates Poor
} 
there was sufficlent income for the family needs. The father and mother were high school graduates that were interested in giving their child more advantages than they had had, but they were over-protective parents and Pupil No. 5 had not learned to be independent. Pupli No, 5 had many books and had been taken on many trips, but she had had no children with whom to play and on entering school she did not know how to cooperate or share with others in her group. Her attention span was too short for simple directions. As she had never been away from her mother, she depended on her for everything. She was emotionally upset on being placed in an unfamiliar situation. Her general health and attendance were good as she missed only eight days during the school year.

Pup11 No. 6 entered flrst grade in September 1951 with a C.A. of flve years, eleven months. On the Reading Readiness Test she made a low normal score. Her score on the Intelligence Test was 110. From the I.Q. score her mental age was found to be six years, six months. The scores on the test Indicated that Pupil No. 6 would have success in learning to read her first year in school.

An investigation of the family background revealed that Pup11 No. 6 came from a home in which there were five other chlldren. Two were younger than Pup11 No. 6. The father and mother were high school graduates and both worked in order to have sufficient funds for the family. The mother's mother lived with them and took care of the children. Pupil 
No. 6 was spoiled, in that she was used to having her own way at home, and had a temper tantrum when she could not have her own way at school. She did not cooperate or share with the others in her group. She was a beautiful child, and as her grandmother did everything for her at home, she had not developed independence. She did not, during the entire jear, develope the ability to listen to a story through, and two or three simple directions were too much for her to follow. Her health and attendance in school were good. She missed only ten days during the school year.

Pup11 No. 14 came from a family with an above average income. The father was a college praduate. The mother a high school graduate. There were two other children in the family. Pupil No. 14 was the only girl in the family and was favored by both parents. The parents of Pupil No. 14 had been so glad when a little girl came to their home that they made the boys give in to her at all times. She was not happy unless she was the center of attention. She brought numerous things to school but refused to share them with the group. She refused to cooperate either at work or play unless she could be the leader or have the cholce task. She had been dependent on her mother for everything, and it was nearing the end of her first year in school before she was successful in learning to tie her shoe and properly adjust her wraps. Her general health and attendance in school were good. She missed only fifteen days during the jear. 
Pup11 No. 24 entered first grade in September 1951 with a C.A. of six years. On the Reading Readiness Test he made an average score. His Intelligence score on the Test given that same year was 109 with a mental age of $\mathrm{s} 1 \mathrm{x}$ jears, $81 \mathrm{x}$ months. The test scores would indicate that he would have success in learning to read his first year in school.

A stuay of the family background revealed that Pup1l 10. 24 came from a low income family. The father and mother were both high school graduates. The parents were able to give the chiloren few advantages but they gave them much love and encouragement. Pupil No. 24 was a timid child. He wanted to work alone and was not happy in the group elther at work or play. He had a tendency to take the belongings of others and 1t was not unt11 the end of his first year in school that this tendency was conquered. He was a listless listener and could not follow a short story through. Two or three simple directions were too much for him to follow. His general health and attendance in school were good. He missed only six days during the school year.

The subjects in each case study clted were old enough chronologically to be in school, each had a mental age of as much as $\$ 1 x$ years, three months, and all had average intelligence or better. They were a.1 lacking in social-emotional readiness and so were not able to recelve fomal reading instruction their first year in school. 
Evidence to support the contention that the sociallyemotionally well-adjusted subjects were successful in learnIng to read was obtained from the Metropolitan Achlevement Test. The results of that test, given in Table XIII, show that the median score for the test in word picture was 26. The mean score was 26.5 with a standard deviation of 4.32 . There was a range of seventeen on the test. All of the subjects scored a grade equivalent of second grade or above on the test.

The Word Recognition Test results given in Table XIII show that the median for the test was 20 , the mean was 19.5 with a standard deviation of 4.66. There was a range of twelve on the test. Five of the subjects did not score as high as twenty, which was the equivalent of second grade. There were seven subjects who made a score having a grade equivalent of 2.5 or above.

The Word lleaning Test results given in Table XIII show that the median for the test was nineteen, the mean 19.8 with a standard deviation of 3.63. There was a range of thirteen on the test. All of the subjects made a score which was equivalent to second grade on that test. There were four subjects who made a score with a grade equivalent less than 2.5 . Four of the subjects made a score which was equivalent to third grade. 
THE SUBTEST SCORES AND AVERAGE GRADE PLACEMENT

OF THIRTY-FOUR FIRST GRADE PUPILS OBTAINED

FROM THE METROPOLITAN ACHIEVEMENT

TEST ADMINISTERED ON

MAY 5,1952

TABLE XIII

\begin{tabular}{llllll}
\hline $\begin{array}{l}\text { Case } \\
\text { No. }\end{array}$ & Word & Word & Word & Mumbers & Grade \\
Plcture & Recognition & Meaning & & Placemen \\
\hline 1 & 31 & 25 & 26 & 67 & 3.3 \\
2 & 26 & 16 & 20 & 56 & 2.3 \\
3 & 22 & 16 & 19 & 67 & 2.7 \\
4 & 34 & 23 & 18 & 62 & 2.8
\end{tabular}

$* 5$

*6

7

8

9

10

11

12

13

$* 14$

15

16

17

18

19

20

21

22

23

*24

25

26

27

28

29

30

31

32

33

34

34

26

29

27

32

29

20

28

27

27

35

21

25

28

20

22

20

37

28

26

25

22

23

24

21

24
20

20

23

22

20

18

16

2I

2I

18

25

16

20

20

21

18

17

20

23

13

20

20

21

24

20

18
22

22

25

25

20

26

19

19

24

14

16

18

26

24

18

13

17

17

18

14

20

20

20

17

20

18
61

63

64

61

60

52

51

2.6

2.6

2.8

2.6

2.5

2.5

2.2

62

54

65

63

56

60

65

53

64

2.5

2.4

2.6

2.9

2.2

2.6

2.8

2.3

2.5

66

55

67

63

67

53

60

63

57

65
2. 6

2.5

2.9

2.4

2.5

2.3

2.5

2.7

2.4

2.6 
The liumbers Test results given in Table XIII show that the median for the test was sixty-one, the mean 60.5 with a standard deviation of 4.41 . There was a range of sixteen on the test. All of the subjects made a score which was equivalent to second grade. Twelve of the subjects made a score which was equivalent to third grade. Three subjects made a score which was equivalent to fourth grade.

On average grade equivalent as shown in Table XIII a.1 the subjects made a score which was equivalent to second grade. Twenty-two of the subjects made a score which was equivalent to 2.5 or more. One subject made a score which was equivalent to third grade.

Four of the subjects studied in the group were not given the test, as they were in the Junior Primary Group and had not had formal reading instruction.

The data presented from the Hetropolitan Achievement Test results would seem to inaicate that subjects who are capable of reading because of chronological age and mental age would succeed in learning to read if they were well adjusted both socially and emotionally. 
CHAPTER V

SOCIAL-EMOTIONAL READINESS OF THIRTY-FOUR FIRST GRADE PUPIIS 
CHAPTBR VI

THE RTSUITS OF THE SOCTOMETRIC TESTS

Further evidence to support the contention that the socially-emotionally well-adjusted subjects are more successful in school life was obtained from Soclometric tests which were administered three times during the school year.

The first Sociometric Test was administered in october. All the subjects had been together in a group since the openInf of school in September, so they were well acquainted in the group. The test was administered to thirty-four subjects.

Flgure I shows the soclogram which was charted from answers to the flrst test, "Who would it be?" The question asiced was, "If you could have for your partner today anyone In your room, who would it be?" The question was first charted with the nineteen boys. Pupil No. 31 was chosen by twelve of the boys. Pupil No. 31 had been in school the previous year subjected to an intensive readiness program. He had learned to cooperate with others, he was a good listener, but he did not follow directions well. He was an extremely nervous child and had trouble controlling his temper. As he had been in school the previous year and knew more about the organization of school life he became the leader of the boys the first week in school. Pupil No. 27 was chosen by three of the boys. Pupil No. 27 knew how to cooperate 


\section{FIGURE I}

\section{FIRST CHOICE OF THE BOYS FOR FRIEIDS WHOM THEY WOULD} IIKE TO HAVE FOR THEIR PARTNER FOR THE DAY (OCTOBER)
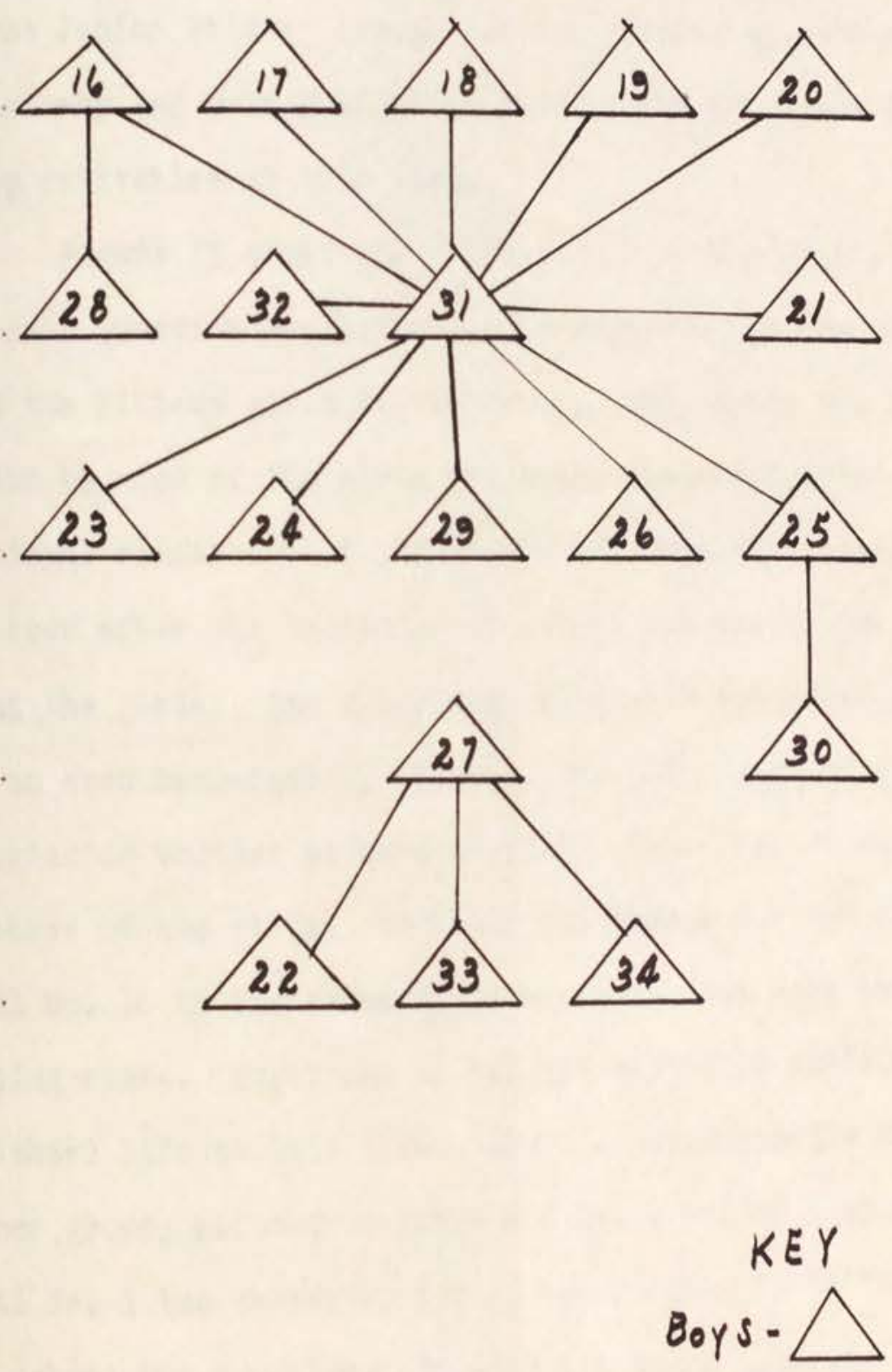
With others in his group, he shared well, was a good listener and seemed to be adjusting satisfactory to school life. Pupil No. 16 and Pupil No. 25, who each were chosen by one boy, were adjusting satisfactory to school life. Probably the reason for the choice of those two boys was that they were playmates at home. Pup11 No. 24, who was later placed in the Junior Primary Group, did not receive any votes. He was so shy and poorly adjusted that he did not enter into any group activities at this time.

Figure II shows the soclogram which was charted from the same question as that asked in Figure I but the subjects were the fifteen girls in the group. Here again the girl chosen by nine of the girls was rated satisfactory on socialemotional readiness. Pupil No. 10 had been to Kindergarten and soon after the beginning of school had become the leader among the girls. She cooperated well with the other girls, had an even temperament, and made herself a part of every undertaking whether at work or play. Pupil No. 15 was chosen by three of the firls. Probably the reason for the choice of Pupil No. 15 by the three firls was that they were in the same dancing class. Pup1l No. 15 was not adjusting satisfactory to school life at this time. She did not cooperate with all in her group, refused to share and had a sullen disposition. Pupil No. 1 was chosen by two of the girls. Those three rode the school bus together. Pupil No. I was a beautiful child 


\section{FIGURE II}

FIRST CHOICE OF THE GIRLS FOR FRIEIDS WHO THEY WOULD LIKE TO HAVE FOR THEIR PARTITER FOR THE DAY (OCTOBER)

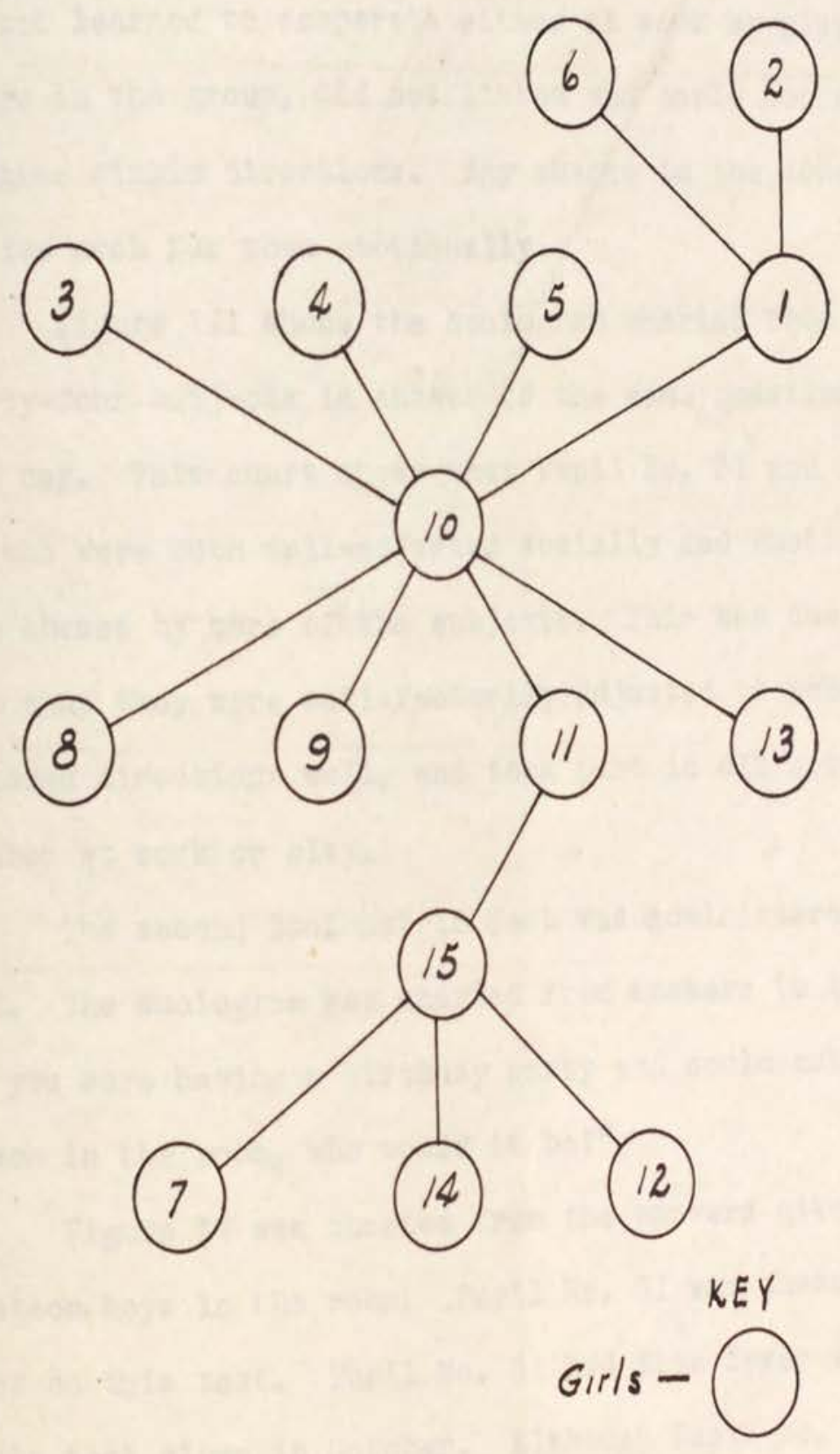


but emotionally unstable. She did not know how to cooperate with others, refused to share, her attention span was short and she had a temper tantrum when she could not have her own way. Pupils No. 5, 6, and 14, who were later placed in the Junior Primary Group, did not receive any votes at this time. They were not adjusting satisfactory to school life. They had not learned to cooperate elther at work or play with others in the group, did not 11sten and could not follow two or three simple directions. Any change in the school routine was too much for them emotionally.

F1gure III shows the soclogram charted from all the thirty-four subjects in answer to the same question on the same day. This chart shows that Pupil No. 31 and Pupil No. 10, who were both well-adjusted socially and emotionally, were chosen by more of the subjects. This was due to the fact that they were satisfactorily adjusted to school Iife, followed directions well, and took part in all activities whether at work or play.

The second Sociometric Test was administered in January 1952. The soclogram was charted from answers to the question, "If you were having a birthday party and could ask only one person in the room, who would it be?"

Figure IV was charted from the answers given by the nineteen boys in the room. Pupil No. 31 was chosen seven times on this test. Pupil No. 31 had five fewer votes than on the test given in October. Although Pup1l No. 31 was 


\section{FIGURE III}

PIRST CHOISE OF THE SUBJECTS FOR FRTENDS WHO THEY WOULD LIKE FOR THEIR PARTNER CHARTED BOYS AND GIRLS TOGETHER (OCTOBRR)
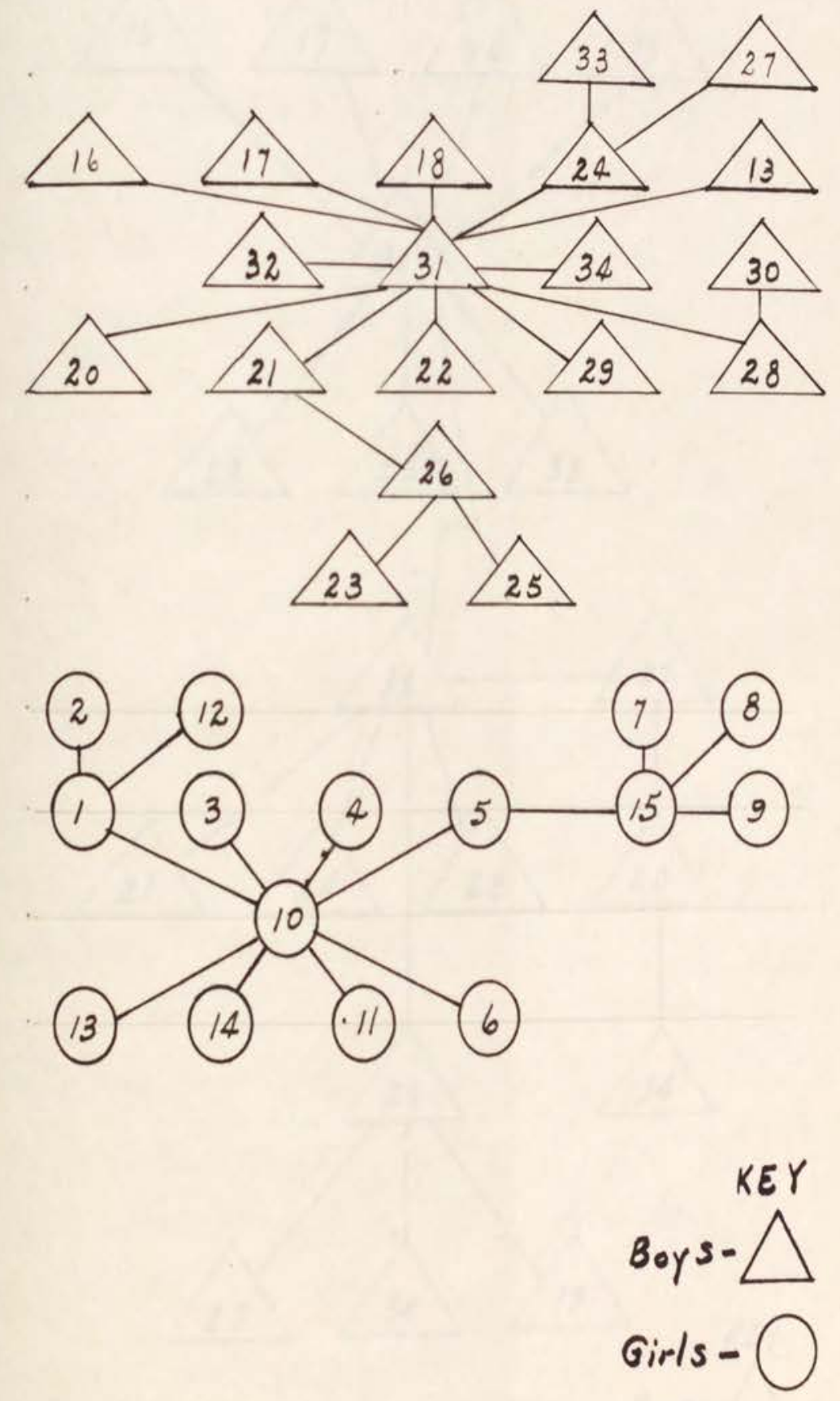


\section{FIGURE IV}

FIRST CHOICE OF THE BOYS FOR RRIENDS WHO THEY WOULD LTKE TO HAVE AT THEIR PARTY

(JAIUARY)

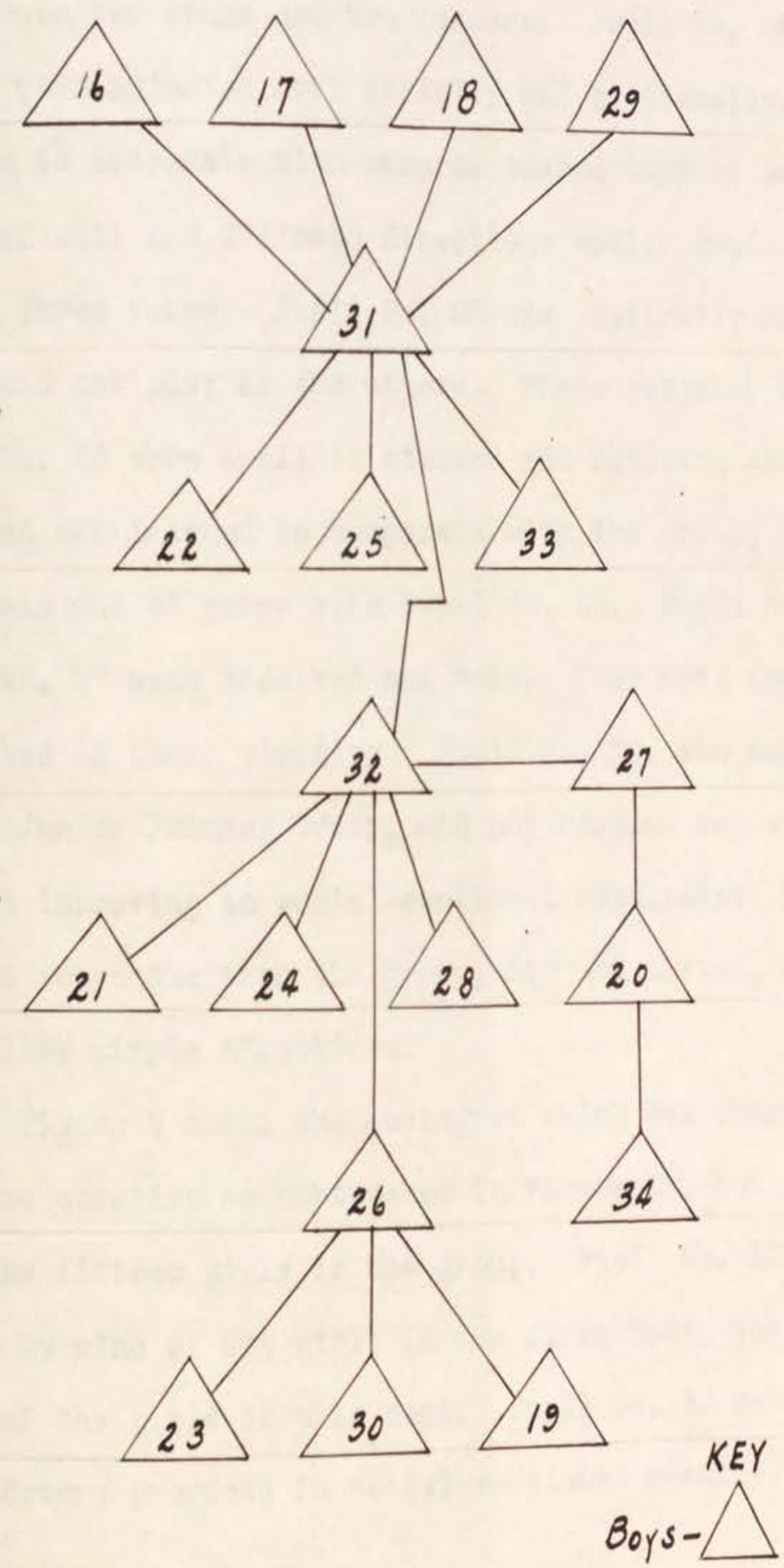


adjusting satisfactory to school life, he had become too dictatorial with the children and as they became more adjusted, they were beginning to make other friends. Pupil No. 32 received six votes. Pup 11 No. 32 was becoming more popular with the boys. Instead of one gang in the group, now there were two gangs and two leaders. Pupil No, 32 was becoming well adjusted both soclally and emotionally. He had learned to cooperate with others, shared toys or materials, listened well and followed directions well. Pupil No. 26 recelved three votes. Pup1l No. 26 was physicaliy handicapped and could not play as the others. Those subjects who chose Pupil No. 26 were small in stature and retiring children. They had not learned to cooperate with the group, and chose to remain out of games with Pupil No. 26. Pupil No. 20 and Pup11 No. 27 each recelved one vote. They were from boys who 11 ved in their vicinity. Pupil No. 24, who was placed In the Junior Primary Group, did not receive any votes. He was not improving in social-emotional readiness. He still did not cooperate with the group, did not listen, and could not follow simple directions.

Figure $V$ shows the soclogram which was charted from the same question as that asked in Figure IV, but the subjects were the fifteen girls in the group. Pupil No. 10, who was chosen by nine of the girls in the flrst test, was chosen by eight of the girls on this test. Pupil No. 10 was making satisfactory progress in social-emotional readiness at the 


\section{DJours v}

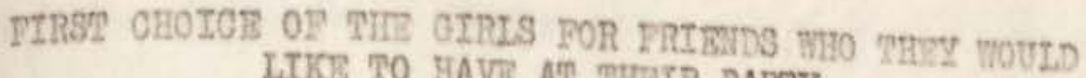
LTKE TO HAVE AT TIRTR PARYY (JMITARY)

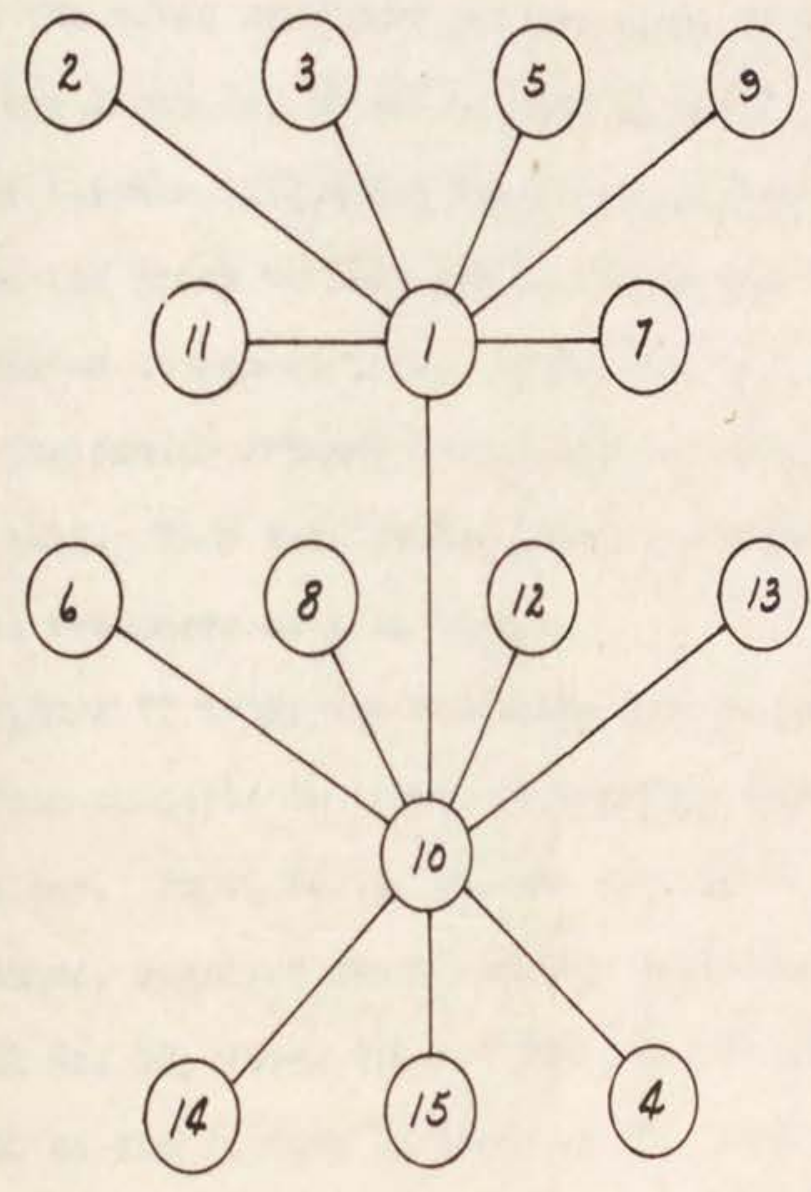

$$
\text { Girls - KEY }
$$


time of the first test and was still. Improving at the time of this test. Pupil No. I shared the votes with Pupil No.10. pupil No. 1, who was lacking in social-emotional readiness at the time of the first test, was not making satisfactory progress at this time. She still did not cooperate with the group, refused to share, was dependent, and did not listen. That all the votes were cast for two girls in the group seemed odd, but Pupil No. 10 was noticeably still the leader, while the teacher influenced the choice of Pupil No. 1 as she had asked the group to help her in aiding Pupil No. I to become adjusted to school life. Pupils No. 5, 6, and 14, who were in the Junior Primary Group, did not receive any votes on this test. They were making little progress in socialemotional readiness at this time.

Figure VI shows the soclogram charted from all the thirty-four subjects in answer to the same question given on the same day. Pupil No. 1, who was lacking in social-omotional readiness, received twelve votes. Pupil No. 31, six votes and Pupil No. 10, seven votes. Pupil No. 31 and Pupil No. 10 seemed to be the leaders in their group. They were both welladjusted both soclally and emotionally. Pupil No. 32 recoived three votes. He was also well-adjusted. Pupil No. 1, who received the most votes on this test, was probably chosen as a result of the teacher's influence in asicing the aid of the group in helping Pupil No. I become better adjusted to school 11fe. Pupils No. 4, 6, 14 and 24 did not recelve any votes 


\section{FIOURE VI}

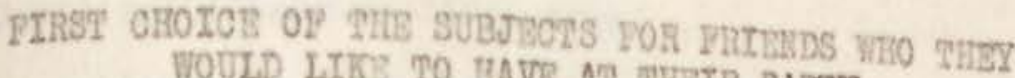 WOULD LIKS TO HAVS AT THEIR PARTY} (JAIUARY)
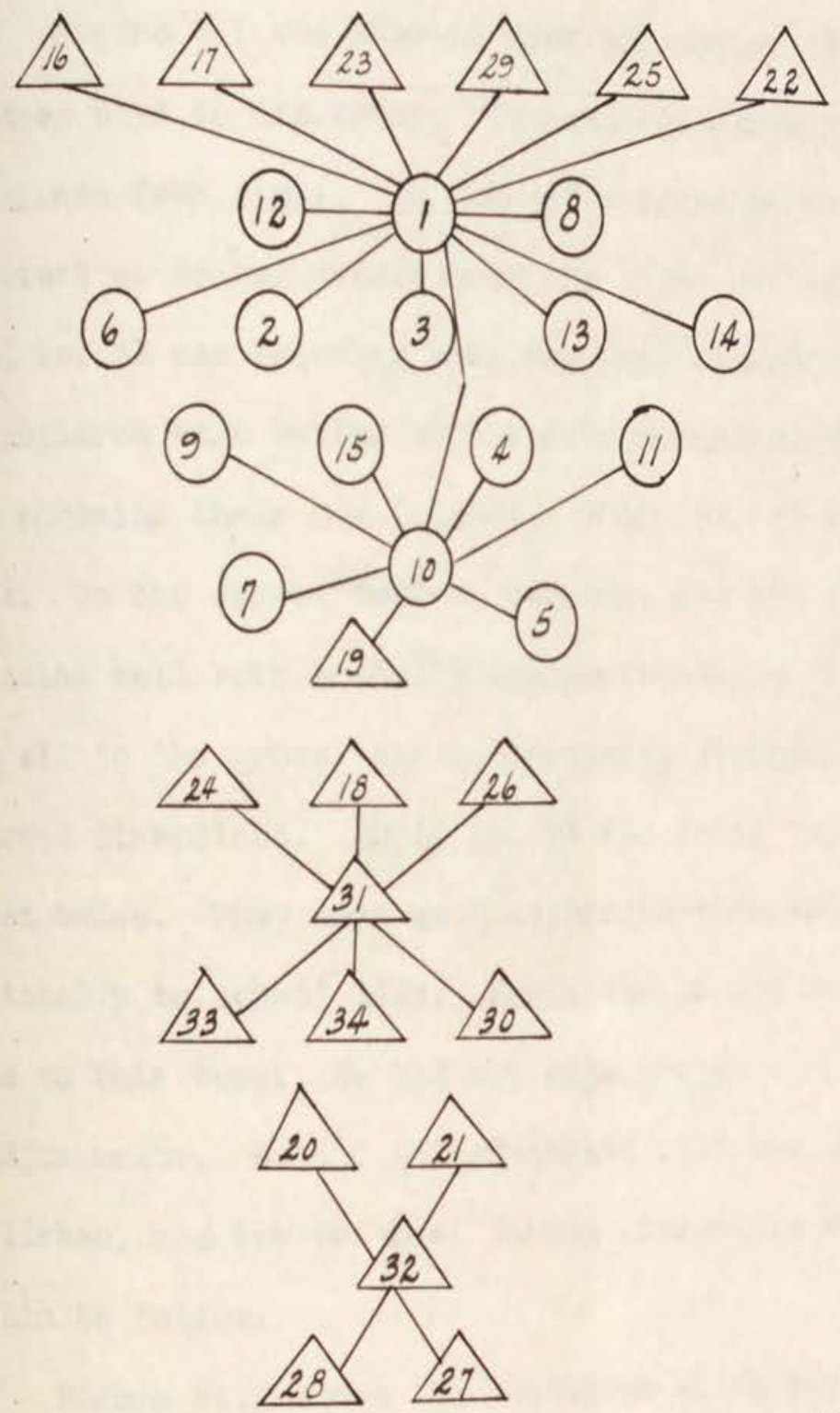

$$
\text { Boys- }
$$


on this test. They were not making satisfactory socialemotional adjustment at this time.

The third Sociometric Test was administered in May 1952. The soclogram was charted from answers to the question, "If you could invite only one person in the room to your house for dinner, who would it be?"

Elgure VII who charted from the answers given by the nineteen boys in the group. In this sociogram Pupil No. 31 was chosen four times. He did not recelve as many votes on this test as he had recelved on the first and second tests. Pup11 No. 31 was becoming more and more dictatorial, and as the children were better adjusted to school at this time, they were choosing their own friends. Pupil No. 32 was chosen five times. On the second test he had received six votes. He was adjusting well both soclally and emotionally. He cooperated with all in the group, was independent, listened well and followed directions. Pupil No. 23 and Pupil No. 26 were each chosen twice. They were each adjusting both socially and emotionally to school life. Pup1l No. 24 did not recelve any votes on this test. He had not made proper social or emotional adjustments, He did not cooperate with the group, could not listen, and two or three simple directions were too much for him to follow.

Figure VIII shows the soclogram which was charted from the same question as that asked in Figure VII, but the subjects were the fifteen girls in the group. Here again, 


\section{FIGURE VII}

FIRST CHOICE OF THE BOYS FOR FRIBUDS WHO THEY WOULD LIKE TO HAVE AS GUESTS FOR DINNER (MAY)
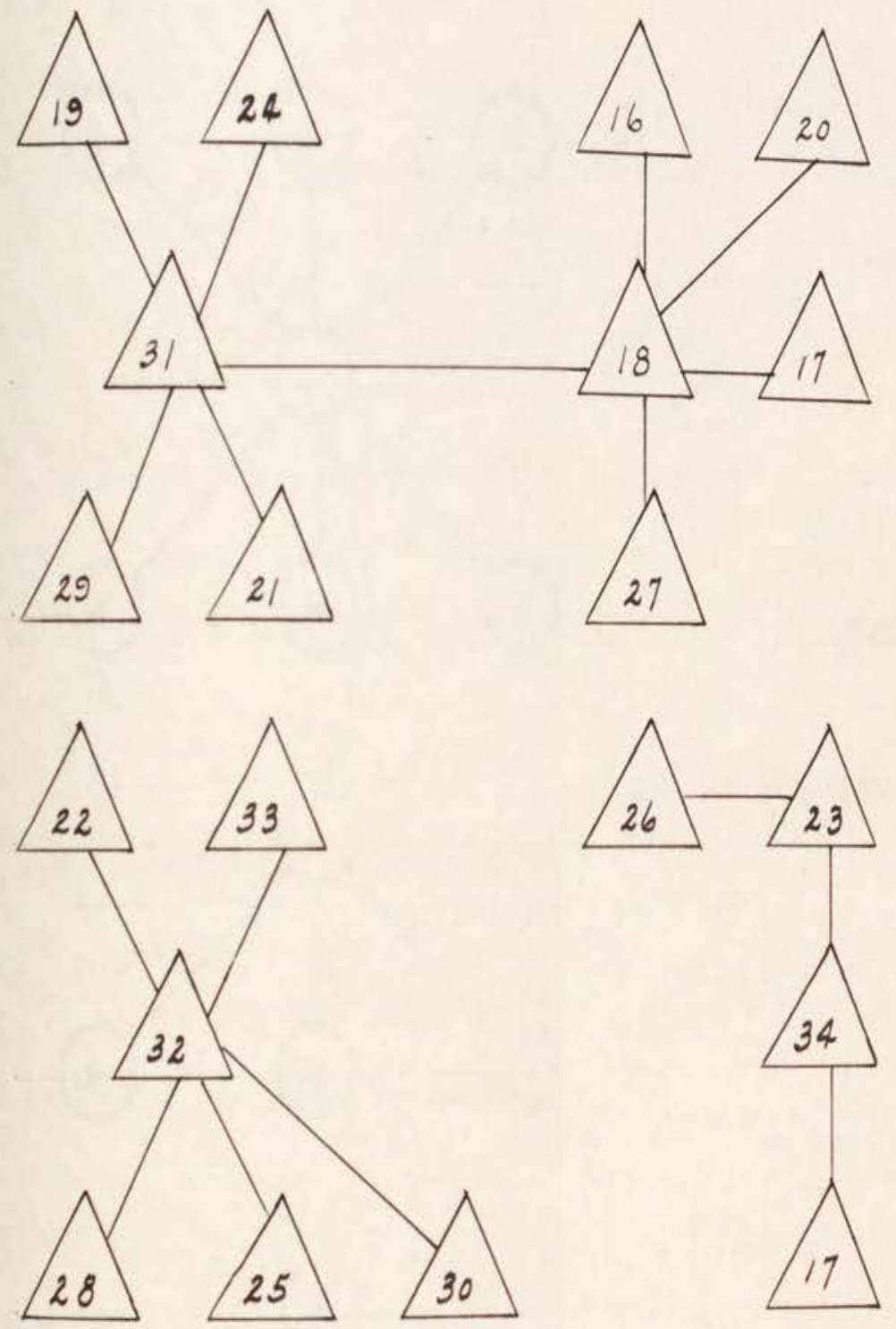

$$
\text { Boys - } \triangle
$$




\section{FIGUR: VIII}

FIRST CHOTCE OF THE GIRLS FOR FRIENDS WHO THEY WOULD LIKE TO HAVE AS GUESTS FOR DINNER
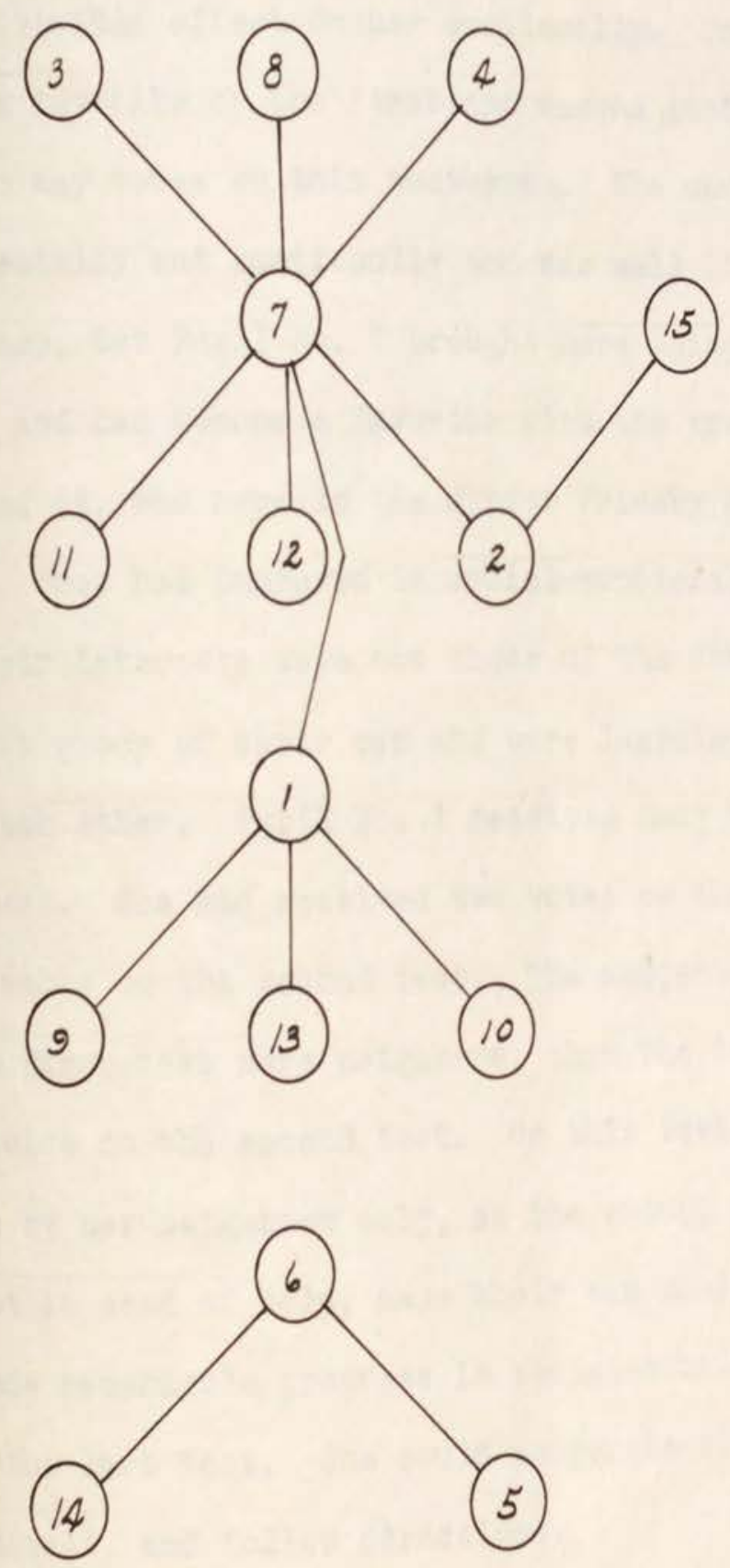
pupil No. 7, the girl chosen by six of the girls, was welladjusted both socially and emotionally. Pupil No, 7 had not been chosen on the other two tests but she had fast developed Into the leader of her group. She cooperated well with the group, shared toys or materials, was a good listener, and changes in school organization or schedules had no visible effect on her emotionally. Pupil No. 10, who mas the favorite on the first and second soclogram, did not recelve any votes on this soclogram. She was well-adjusted both soclally and emotionally and was well liked by all in her group, but Pup1l No. 7 brought more things to school to share, and had become a favorite with the group. Pupils No. 5,6, and 14, who were in the Junlor Primary Group, chose each other. They had improved in social-emotional adjustments, but their interests were not those of the others so they had formed a group of their own and were learning to cooperate with each other. Pupil No. 1 recelved only two votes on this test. She had recelved two votes on the first test and seven votes on the second test. The subjects who chose her on the first test were neighbors, then the teacher influenced her choice on the second test. On this test Pup1l No. I was chosen by her neighbors only, as the group, knowing that she was not in need of help, made their own choices. Pupli No. 1 had made remarkable progress in social-emotional adjustment since the last test. She could cooperate with her group, listen well, and follow directions. 
Figure IX shows the sociogram which was charted from the thirty-four subjects in answer to the same question on the same day. Pupil No. 7 was chosen seven times, Pupil No. 32 was chosen three times, and Pupil No. 18 was chosen five times. Here again, the subjects chosen were well-adjusted both socially and emotionally. Each of them cooperated well with the group, shared, were independent, listened, could follow directions and change in schedule or organization had no visible effect on them. Pupils No. 5, 6, 14 and 24, who were in the Junior Primary Group, again chose each other as their interests were the same.

The three sociograms charted at three different periods of the year would seem to indicate that the subjects who are well-adjusted both socially and emotionally become leaders in their group. 


\section{FIGURE IX}

FIRST CHOICE OF THE SUBJBCTS FOR FRIENDS WHO THEY WOULD IIKTE TO HAVE AS GUESTS FOR DINNBR

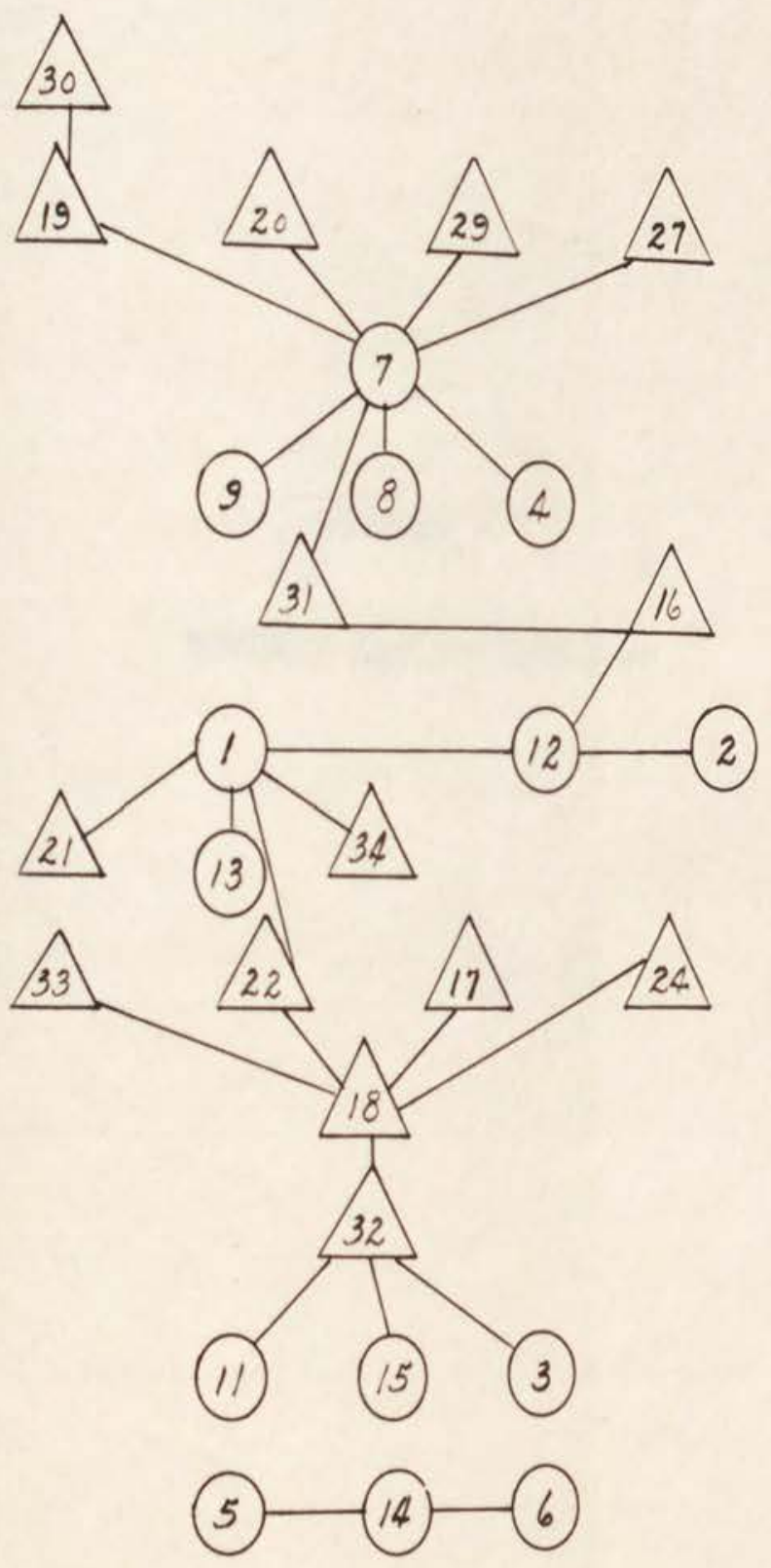

$$
\text { Boys- } \triangle
$$


CHAPTER VII

SUMMARY AND CONCLUSIONS 


\section{CHAPTER VII \\ SURMARY AND CONCLUSIONS}

This study to determine the relationship of soclalemotional maturity to learning achlevement was made of first grade children In an elementary school in Jefferson County. Thirty-four chlldren were used in the study. There were nineteen boys and fifteen glrls. The ages ranged from five years, eleven months to seven years.

The Intelligence scores as obtalned from the KuhlmanAnderson Test ranged from 96 to 123. The mean test score was 106.17. There were no subjects who made a below average score on the test. The mental age of the subjects as obtalned from the same test ranged from six years, three months to seven years, four months.

The Reading Readiness status as obtalned from the Letropolitan Readiness Test show that tinirty-three of the subjects made a score of average or above on the test. The one who made a score of low normal had an Intelligence score of 103. On the Number Readiness Test the subjects all made a score of average or above. Thirty-one of the subjects made a score of average or above on the Total Readiness Test. Three made a score of low normal. Two of those subjects malkIng a low normal score had a chronological age of less than sis years, six months. The other who made a low normal score had a chronological age of more than $s 1 x$ years, six months. 
The subjects used in this study had few childhood diseases while in the first grade with the exception of eleven cases of measles. Nany had had measles and chickenpox before entering school. Six subjects had their tonsils removod during the year. The hearing and eyesight were normal rith two exceptions, two of the subjects wore glasses to straighten the muscles of their eyes. The teeth of the subjects were good as only six of them were found to have teeth which were in poor condition. During the jear, the class gained an average of 4.- pounds in weight, and all of the subjects showed a gain in helght of as much as one inch for the perlod studied.

From a study of the home background, it was found that most of these subjects came from good homes. There were only three working mothers and there was no problem presented by the mothers who were working. Nost of the families owned their own homes.

From the Soc1al-Emotional check made by the teacher, thirteen of the subjects were not ready for formal reading Instruction at the time the observation was made by the teacher. Four of those thirteen were not to reach the level of social-emotional readiness necessary for success in learnIng to read their first year in school.

The achlevement of the subjects in first grade work was found by use of the Netropolitan Achievement Iest. All the subjects taking the test made a score which was equivalent 
to second grade. Twenty-two of the subjects made a score wilch was equivalent to 2.5 or more.

The following conclusions were reached:

1. Children who are capable of learning to read because of chronological age and mental age may not succeed in learning to read because of the lack of social-emotional readiness.

2. In this study the subjects with a younger chron0logical age scored higher on an Intelligence Test than subjects with an older chronological age.

3. The health of these subjects was good. The gain In weight and height was what is expected of the average child of this age.

4. The homes from which these subjects came seem to be about what would be expected in an average group.

5. Chilaren seem to choose those subjects who are mell-adjusted both socially and emotionally as leaders of their group. 


\section{BIBLIOGRAPHY}

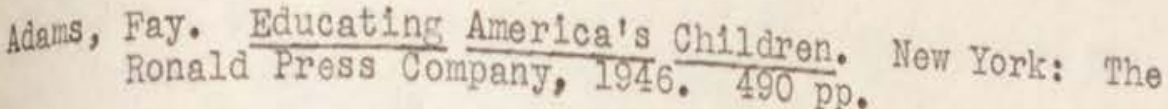
Adams, Fay, Gray, Lillian. Reese, Dora, Teaching Children $\frac{T 0}{52} 5 \frac{\text { Read. Np. New York: The Ronald Press Company, } 1949 .}{\mathrm{pp}}$

A Good Start In School. State of Indiana Department of PubIic Instruction, Bulletin No. 158. Indianapolis, 1949. 171-182 pp.

Betts, Emmett. Foundations of Reading Instruction. Chicago:

Bond, Guy and Bond, Eva. Teaching The Child To Read. New York: The liaclulian Company, 19 $\overline{48 .} 3 \overline{56}$ pp.

Boney, C. DeWltt. "Shall Beginning Reading Be Delayed?" $\frac{\text { Journal }}{\text { Vol. } 26: \frac{15}{156-161 . ~ D e c o m b e r ~}} \frac{\text { Association for }}{1949 \text {. }}$. Education.

The Courier-Journal. December 15, 1951.

Durrell, Donald D. "Individual Differences and Their Implications With Respect to Instruction in Reading." The Thirty-Sixth Yearbook of the National Society for Education. Part I. (Chicago: The National soclety for the Study of Education, 1937). pp. 325-356. $442 \mathrm{pp}$.

Gans, Roma. "How Do We Know When Children Are Ready to Read?" Journal of Assoclation for Childhood Education. Vol. 26:152-155. December 1949.

Gates, Arthur I. "The Necessary lental Age for Beginning Reading". Elementary School Journal. Vol. 37:497-508. March 1937 .

Gesell, Arnold and Ilg, Grances, The Child From Five To Ten. New York: Harper \& Brothers, 1947. $475 \mathrm{pp}$.

Handbook for Junior Primary Teachers. Revised Edition. Division of Instruction. Richmond Public Schools, 1949. pp. 144.

Hildreth, Gertrude. Learning The Three R's. Nashville: Educational publishers, Inc., 1936. 824 pp. 

Jenkins, Gladys, et al. These
Scott, Foresman, $1 \frac{\text { Are }}{948 .} \frac{\text { Your }}{192}$ Children. Chicago:

Letter from Miss Arline Young, Covington, Kentucky to Mrs. Suda Butler, January 2, 1952.

McKee, Paul. The Teaching of Reading. New York: Houghton Mifflin Company, 1948. $622 \mathrm{pp}$.

Morphett, M. V. and Washburne, C. "When Should Children Begin To Read?" Elementary School Journal. Vol. 31: 496-503. No. 7. March 1931.

The Primary Manual. Curriculum Bulletin 95. The Cincinnati Public Schools, Cincinnati, Ohio. 1951. 577 pp.

Russell, David H. "Reading and Child Development". The Forty-Eighth Yearbook of the National Society for Education. 1949. pp. II-32. $343 \mathrm{pp}$.

Whitty, Paul. Reading in Modern Education. Boston: D. C. Heath and Company, $\overline{1949 .} 307 \mathrm{pp}$.

Wilshinger, D. M. "Summary of Reading Readiness Research." Educational Administration and Supervision. XXXIV. october 1948. 372-376. 